\title{
Environmental Implementation Plan (U)
}

by

G. L. Peterson

Westinghouse Savannah River Company

Savannah River Site

Aiken, South Carolina 29808

DOE Contract No. DE-AC09-89SR18035

This paper was prepared in connection with work done under the above contract number with the U.S.

Department of Energy. By acceptance of this paper, the publisher and/or recipient acknowledges the U.S.

Government's right to retain a nonexclusive, royalty-free license in and to any copyright covering this paper, along with the right to reproduce and to authorize others to reproduce all or part of the copyrighted paper. 


\section{DISCLAIMER}

This report was prepared as an account of work sponsored by an agency of the United States Government. Neither the United States Government nor any agency thereof, nor any of their employees, makes any warranty, express or implied, or assumes any legal liability or responsibility for the accuracy, completeness, or usefulness of any information, apparatus, product, or process disclosed, or represents that its use would not infringe privately owned rights. Reference herein to any specific commercial product, process, or service by trade name, trademark, manufacturer, or otherwise does not necessarily constitute or imply its endorsement, recommendation, or favoring by the United States Government or any agency thereof. The views and opinions of authors expressed herein do not necessarily state or reflect those of the United States Government or any agency thereof.

This report has been reproduced directly from the best available copy.

Available to DOE and DOE contractors from the Office of Scientific and Technical Information, P.O. Box 62, Oak Ridge, TN 37831; prices available from (615) 576-8401.

Available to the public from the National Technical Information Service, U.S. Department of Commerce, 5285 Port Royal Road, Springfield, VA 22161. 


\section{DISCLAIMER}

Portions of this document may be illegible in electronic image products. Images are produced from the best available original document. 


\section{Chapter 20}

\section{Environmental Summary}

Chapter was compiled and reviewed by Greg Peterson.

Site Program Overview

Environmental Program Plans for:

GSA

SREL

SRFS

US SCS

8

15

26

WSI

WSRC

32

E \& PD

Construction Management

32

HLW

Defense Waste Processing Facility

41

High Level Waste

52

NMPD

Separations

63

Tritium

74

RD

Reactor

83

Reactor Materials

90

SRTC

Savannah River Technology Center
ODD PAG

We $S \leq 2 T 100$

15

6
0

2


SSD

Analytical Laboratories

125

Central Services Works Engineering

127

Site Services Engineering

138

Site Services Training

144

Transportation

147

SW\& ER

Environmental Restoration

151

Solid Waste

159 
The United States Department of Energy (DOE) and the managing contractor Westinghouse Savannah River Company (WSRC), are committed to operating the SRS in a manner that protects the public health and safety, and the environment. This philosophy is contained in DOE Order 5400.1, General Environmental Protection Program, the SRS Strategic Environmental Plan, and in the SRS Mission, Vision, and Principles.

Compliance with environmental regulations and U. S. Department of Energy orders relating to environmental protection is an important part of the SRS program. Demonstrating environmental excellence is a high priority site initiative embodied in DOE and WSRC policy. SRS is constantly striving to improve its standing as a leader in environmental protection activities.

All activities at SRS are overseen by one or more regulators, such as South Carolina Department of Health and Environmental Control (SCDHEC) and the Environmental Protection Agency (EPA).

Over the past few years, the number of environmental regulations has continued to increase. In chapter two the strategy to reach our site goal of environmental excellence and compliance with new and existing environmental regulations and DOE orders is described.

In this chapter, SRS environmental programs and plans from DOE contractors and WSRC divisions/departments are presented along with the environmental coordinator for each program. The objectives of this chapter are to enhance communication of existing or planned programs in order to do the following:

- identify activities required for meeting environmental needs

- identify needed resources and a schedule to accomplish those activities

- promote share-savings and consistency in those activities through teamwork,proactive planning, and a common vision

The consolidated environmental plans and initiatives of individual organizations and divisions form a long-range environmental-protection plan which fulfill the requirements of DOE Order 5400.1, and provides SRS with a road map for the what, when, how, and why for environmental requirements.

This chapter of the EIP is designed to integrated with and complement the planning and budget process of WSRC individual departments and divisions, and with the SRS Site Development Plan. Detailed planning and financial information is provided in their annual operating programs, five-year plans, and other planning documents. 
In Chapter 20, Environmental Summary, environmental plans are arranged by contractors/divisions in alphabetical order. For each organization listed, the programs reported follow the order of EIP's table of contents. Table 20-1 is a matrix which indicates the programs reported for the following chapters by each department:

\section{Chapter Title}

Chemical Management, Pollution Prevention, and Other Compliance Programs

Natural Resource Protection (Land, Wildlife, \& Surface Water)

7

Groundwater Protection

8

Waste Management and Disposal

9

Atmospheric Protection Programs

10

Environmental Restoration 
Table 20-1. Environmental Plans Reported

Plans listed for EIP Programs from chapters:

Contractor/Division/Department

5

6

8

9

10

GSA

SREL

SRFS

US SCS

$\mathrm{X}$

$\mathrm{X}$

$\mathrm{X}$

WSI

WSRC

E \& PD

Construction Management

$\begin{array}{lll}\mathrm{X} & \mathrm{X} & \mathrm{X}\end{array}$

HLW

Defense Waste Processing Facility

High Level Waste

$\begin{array}{ccccc}X & X & X & X & X \\ X & X & X & X & X\end{array}$

NMPD

Separations

Tritium

$\begin{array}{ll}\mathrm{X} & \mathrm{X} \\ \mathrm{X} & \mathrm{X}\end{array}$

$\mathrm{X}$

$\mathrm{X}$

$\mathrm{X}$

$\mathrm{X} \quad \mathrm{X}$

X

RD

Reactor

Reactor Materials

$\begin{array}{cccccc}\mathrm{X} & \mathrm{X} & \mathrm{X} & \mathrm{X} & \mathrm{X} & \\ \mathrm{X} & \mathrm{X} & & \mathrm{X} & \mathrm{X} & \mathrm{X}\end{array}$

SRTC

Savannah River Technology Center

$\mathrm{X} \quad \mathrm{X}$

$\mathrm{X}$

$\mathrm{X} \quad \mathrm{X}$

SSD

Analytical Laboratories

$\begin{array}{lllll}\mathrm{X} & \mathrm{X} & \mathrm{X} & \mathrm{X} & \\ \mathrm{X} & \mathrm{X} & & \mathrm{X} & \mathrm{X} \\ & & & \mathrm{X} & \end{array}$

Transportation

$\mathrm{X}$

SW\& ER

Environmental Restoration

Solid Waste

$\begin{array}{llllll}X & X & X & X & & X \\ X & X & X & X & X & \end{array}$




\section{GENERAL SERVICES ADMINISTRATION ENVIRONMENTAL SUMMARY}

\section{Division}

Federal Supply Service, Interagency Fleet Management System.

\section{Mission}

The GSA Interagency Fleet Management System is established to provide a centralized source of motor vehicles and related services for Federal executive agencies at a quality level that ensures that the needs of these agencies are met efficiently at the least overall cost to the taxpayer. These services may also be provided to members of the judicial and legislative branches of the Federal Government, as resources permit.

\section{Vision}

The GSA Fleet Management Center vision is to be recognized by our customers as the model of fleet management excellence by providing an efficient, modern vehicle fleet at the lowest possible cost.

\section{Lead Environmental Coordinator}

Mr. Warren (Rick) Baker, 725-2921, Beeper No. 4119

\section{Environmental Coordinator}

Mr. Merton Keith - Alternate, 725-3455

\section{Environmental Accomplishments}

The GSA Fleet Management Center was established on the Savannah River Site on October 1, 1993. Since that time we have designated GSA's first Environmental Coordinator and have implemented an aggressive training plan to enlighten him on SRS' environmental protection requirements. We have developed and implemented policies and procedures which will ensure strict compliance with SRS requirements. 


\section{Environmental Planning}

GSA will continue many of the initiatives developed by Central Services Works Engineering (CSWE) for operations in Building 716-A. These include the recycling of scrap metals and the "hot draining" and crushing of used oil filters. GSA's own initiatives include the replacement of harmful chemicals commonly used in automotive maintenance services with more environmentally "friendly" substitutes wherever possible.

\section{Environmental Challenges \& Issues from Projected Mission Changes during Next Five Years}

Although GSA anticipates no major mission change over the next five years, we do face some exciting challenges. We are dedicated (as well as mandated by federal law) to introducing alternatively fueled vehicles (AFV) into the federal fleet. By Fiscal Year 1999, AFVs must equal 75 percent of acquisitions. This initiative will serve not only to reduce our nation's dependence on foreign oil, but will improve air quality through lower vehicle exhaust emissions. 


\section{Savannah River Ecology Laboratory, (SREL) Environmental Summary}

\section{Mission}

The mission of Savannah River Ecology Laboratory is to expand the understanding of ecological principles through interdisciplinary, fieldoriented research and to communicate this knowledge to the scientific community, government agencies and the general public. By doing so we will enhance the international reputation of SREL and the Savannah River Site as a center of ecological field research, education, and service. Special emphasis will be placed on research that evaluates the impacts of industrial and land use technologies on the environment. The SREL mission can best be fulfilled in an atmosphere that fosters academic freedom, safety and environmental protection, and opportunities for faculty, staff, and students to achieve the highest standards of professional and scholarly development.

\section{Vision}

The Savannah River Ecology Laboratory is dedicated to the principle that every human generation deserves to inherit a planet with plentiful natural resources to ensure their social and economic well being. As ecologists, we believe that fully-functioning environmental processes are among the most important of our natural resources. Such processes recycle air, water, and nutrients, and provide for the renewal of fertile soil and plant and animal stocks. We seek to provide the understanding of ecological processes necessary to ensure sustainable future economic development while protecting these crucial ecosystem functions. We also are dedicated to providing the empirical knowledge of ecological principles necessary for the remediation and mitigation of future industrial impacts on these important environmental processes, and for the restoration of ecosystem function in areas previously damaged.

\section{Lead Environmental Coordinator}

Vivian Harper

\section{Environmental Coordinators}

$\begin{array}{ll}\text { Vivian Harper } & \text { RCRA } \\ \text { Vivian Harper } & \text { Environmental Awareness } \\ \text { Warren Safter } & \text { NESHAP }\end{array}$




\section{Environmental Accomplishments}

The Savannah River Ecology Laboratory Environmental Outreach and Education Program was shared with 113,000 people last year. Contacts were made through tours, talks to students and other groups, teacher workshops, and exhibits. The program stresses the importance of environmental awareness in rational decision making in regard to ecological problems. The staff also hopes to inspire program participants to pursue careers in science.

Environmental Outreach programs are scheduled at least two months in advance by calling Tony Mills at 725-9726. Also, environmental education materials, including jigsaw puzzles, are available by calling Tony or Jane Sanders at 725-9724.

SREL maintained custodianship of the 30 DOE Research Set-Aside areas on the SRS. These areas serve as relatively nonimpacted areas for ecological research and as "control" areas for evaluating impacts from SRS site operations and intensive forest management.

\section{Environmental Planning}

Savannah River Ecology Laboratory environmental programs and plans are described in the Natural Resource Management Plan Strategic Guidance, SREL Annual Operating Plan, SREL Annual Technical Progress Report, SREL Strategic Plan, SREL Waste Management Plan, SREL Waste Minimization Plan, SRS Best Management Practices Plan, SRS Spill Prevention Control and Countermeasure Plan, Set-Aside Protection and Management Plan, and the SRS Site Development Plan.

\section{Environmental Challenges \& Issues from Projected Mission Changes during Next Five Years}

In order to respond to changes in projected mission priorities within DOE, SREL must expand and further develop its programs in areas such as restoration/remediation ecology, geographic information systems and landscape ecology, radioecology, toxicology, microbial ecology, and environmental education. Some of the environmental challenges identified for the Savannah River Ecology Laboratory include the following:

- Placing more research emphasis on studies of new methods for restoration and remediation of impacted ecosystems.

- Determining appropriate cleanup standards based on the risk to people and the environment.

- Increasing research studies on the effects of contaminants upon organisms that inhabit impacted natural areas. 
- Developing new technologies in instrumentation and sample preparation necessary for more cost-effective site characterization of contaminated areas.

- Expanding research into processes involved in soil remediation, environmental transport of contaminants, and dose responses of organisms.

- Continuing base-line studies of protected areas to determine standards for comparison with restored ecosystems.

- Building predictive models of remediation and restoration processes as they impact the population structure and genetics of organisms in the environment.

- Providing information relevant to the restoration of wetlands.

- Increasing environmental education to communicate to the public the importance and applicability of the ecological knowledge gained through SREL research. 


\section{Natural Resource Management}

Threatened and Endangered Species

Program Coordinator

Laura L. Janecek

Program Description

Wood Stork

Organizational Responsibility

The SREL Division of Wildlife Ecology and Toxicology conducts research on the breeding biology, foraging ecology, and population genetics of endangered Wood Storks that breed at the Birdsville rookery, adjacent to the SRS. Wood Storks that forage in artificial feeding ponds at Kathwood Lake, on the National Audubon Society's Silver Bluff Plantation Sanctuary, near the SRS, also are studied. Through a cooperative agreement with DOE, the National Audubon Society maintains the Kathwood ponds and SREL monitors the ponds, collects pertinent scientific information, and decides when to make the ponds available to the storks for foraging.

\section{Major Milestones Accomplished in FY 93}

- Documented a maximum of 330 Wood Stork nests at the Birdsville breeding colony; estimated that fledged nestlings per nest was $2.53 \pm 1.11 \mathrm{SD}$, a high level of reproductive success for this colony.

- Thirty-two fledglings were banded with U.S. Fish and Wildlife Service leg bands to facilitate future identification.

- Seven stork nestlings were rescued from fallen nests at the Birdsville colony; all of these birds were transported to St. Catherine's Island Wildlife Survival Center for rehabilitation.

\section{Major Milestones for FY 94}

- Continue research on Birdsville and Kathwood storks.

- Collect shed feathers, blood samples, and egg shell membranes for future molecular genetics studies.

- Continue to band storks for future identification of individuals, to gain knowledge of movement patterns, etc.

Major Milestones for FY 95-99

- Analyze stork prey items for contaminants, to assess the potential impacts of heavy metals, organics, pesticides, and radionuclides on Wood Stork reproductive biology and behavior. 


\section{Natural Resource Management}

\section{Threatened and Endangered Species}

Program Coordinator

Laura L. Janecek

Program Description

Red Cockaded Woodpecker

Organizational Responsibility

The SREL Division of Wildlife Ecology and Toxicology conducts research on the management tactics for maintaining the viability and gene diversity for the endangered Red Cockaded Woodpecker on the SRS. The woodpecker population on the SRS currently is being supplemented by import of birds from other localities of the highly fragmented original range of the Red Cockaded Woodpecker. Wildlife personnel from the Savannah River Forest Station are responsible for management of the woodpeckers while SREL scientists conduct research into aspects of population transplantation and explore management tactics that will better ensure the long-term viability of populations and maintenance of genetic variation. SREL scientists also are investigating the potential competitive interactions between Red Cockaded Woodpeckers and flying squirrels for nest cavities.

\section{Major Milestones Accomplished in FY 93}

- Published a scientific paper detailing the gene dynamics found for highly fragmented populations such as the Red Cockaded Woodpecker.

- Sponsored an SREL Symposium on Spatial and Temporal Population Processes which explored biological and management aspects for species like the Red Cockaded Woodpecker.

- Established three large grid areas for assessing the impact of nest boxes on movements and nesting success of flying squirrels.

\section{Major Milestones for FY 94}

- Publish a scientific paper detailing the effects of genetics on population viabilities. Relate parameters to those found in Red Cockaded Woodpeckers.

- Complete a manuscript detailing the best scenarios for transplantation procedures for maintaining viability and gene diversity.

- Continue monitoring flying squirrel populations relative to nest box augmentation. 


\title{
Natural Resource Management
}

\author{
Biodiversity
}

\section{Program Coordinators}

Laura L. Janecek

Gary R. Wein

\section{Program Description}

SREL conducts biodiversity research to provide information for the development of strategies and options for land managers, at SRS and at similar ecosystems, to enhance biological diversity while utilizing forest resources and operating nuclear facilities. The research programs address short- and long-term effects of management options on the diversity of plant and animal life and allow comparisons of different measures of biological diversity.

\section{Organizational Responsibility}

Two SREL research divisions participate in the SRS Integrated Biodiversity Program: the Division of Wetlands Ecology and the Division of Wildlife Ecology and Toxicology. Within each SREL research division, several independent research programs are conducted by individual faculty members. Other organizations participating in the SRS Integrated Biodiversity Program include the Savannah River Forest Station, WSRC, and the Southeastern Forest Experiment Station.

\section{Major Milestones Accomplished in FY 93}

- Research programs in the Division of Wetlands Ecology focused on the effects of deforestation, land management practices and their effects on plant biodiversity, and the effects of timber management at the timber compartment level.

- Research programs in the Division of Wildlife Ecology and Toxicology focused on censusing of reptiles and amphibians in various habitats of the site, biodiversity of stream fish in impacted vs. nonimpacted site streams, and species interactions and populational diversity of stream fishes of the SRS.

\section{Major Milestones for FY 94}

- An external review of the SRS Integrated Biodiversity Program will be conducted. This will include a scientific review of research projects conducted by all organizations participating in the SRS Biodiversity Program. 


\section{Natural Resource Management}

DOE Research Set-Aside Areas

\section{Program Coordinator}

Laura Janecek

\section{Program Description}

The purpose of the Set-Aside program is to establish lands on the SRS that represent unique and natural habitats of the region, to offer protection to rare, threatened, and endangered biota that inhabit these areas, and to provide sites on the SRS that are conducive to long-term ecological research. In addition, these relatively undisturbed natural areas serve as control sites for evaluating impacts from SRS site operations and intensive forest management activities. Through the Set-Aside program, the protection and preservation of these Areas will not only aid in sustaining a high degree of biological diversity on the site, but also will fulfill DOE's commitment to maintain the SRS as a National Environmental Research Park.

\section{Organizational Responsibility}

SREL serves as custodian of the 30 Set-Aside areas and is responsible for maintaining marked boundary lines, ensuring that the activities of other site land-users do not negatively impact Set-Aside areas, and chairing the Set-Aside Task Group. The SetAside Task Group, under the auspices of the SRS Natural Resources Coordinating Committee, has members from SREL, WSRC, SRFS, and DOE, and serves as the advisory group that ultimately determines how Set-Aside areas will be protected and managed and what activities are appropriate for these areas.

\section{Major Milestones Accomplished in FY 93}

- SREL developed a computer-based geographic information (GIS) data layer describing the Set-Aside boundaries. This GIS layer has been included in the sitewide GIS database to ensure that the Set-Aside areas will be incorporated into future land-use plans for the SRS.

- All Carolina bays in Set-Aside Areas were recommended for inclusion in the EPA's Advanced Identification (ADID) Project, which has as its goal identification and protection of important Carolina bays that remain in South Carolina.

\section{Major Milestones for FY 94}

- Completion of a document detailing information on the soils, floral, and faunal characteristics of each of the 30 Set-Aside areas. This document also will contain a complete bibliography of all research that has been conducted in each Set-Aside area. 


\section{Savannah River Forest Station, (SRFS) Environmental Summary}

Mission

The Savannah River Forest Station, an agency of the United States Department of Agriculture Forest Service, directs the natural resources management program at SRS for endangered species, quality habitats for native wildlife, soil, air and watershed quality, and a healthy forest for environmental research. Activities include timber management; fish, wildlife, and botanical management; secondary road management; wildland fire management; boundary management; soil, water, and air resources management; and forest management research support. The primary mission can be summed up with the phrase, "Caring for the land and serving our customers".

\section{Vision}

The Savannah River Forest Station's vision is to provide a multicultural and diverse organization that is efficient and productive, and excels in achieving its mission.

\section{Lead Environmental Coordinator}

Roger Pitts

\section{Assistant Environmental Coordinator}

Bob Crais

\section{Environmental Accomplishments}

Public Relations

The Savannah River Forest Station environmental awareness programs such as Woodsy Owl, Smokey Bear and career fairs were shared with over 18,000 visitors during 1993. In addition, there were 28 news releases of on-Site news stories.

A multiple use video was developed for use as introductions to meetings, segments of tours and short SRFS orientations. A Natural Resources Environmental Education Program was developed to provide on-Site science and mathematics education for students in third through eighth grades. The program objective is aimed at increasing the student awareness of the role of science and mathematics in providing solutions 
to natural resource and environmental problems. This program is a cooperative effort between the Department of Energy and the University of South Carolina at Aiken and is made available at the Savannah River Forest Station.

For other SRFS environmental accomplishments, refer to the NATURAL RESOURCE MANAGEMENT program descriptions that follow.

\section{Environmental Planning}

Savannah River Forest Station environmental programs and plans are described in the Natural Resource Management Plan (NRMP) Strategic Guidance. Natural Resource Management Operations Plans were written and approved. The Environmental Assessment for the NRMP was approved by DOE Headquarters.

\section{Environmental Challenges \& Issues from Projected Mission Changes during Next Five Years}

Some of the environmental challenges identified for Savannah River Forest Station include the following:

- Increased natural resources research support

- Expansion of the Natural Resources Environmental Education Program for students

- Adjusting management of natural resources to more stringent environmental laws and regulations. 


\title{
Natural Resource Management
}

\author{
Wildlife, Fisheries, and Botany
}

Program Coordinator

Elizabeth LeMaster

Program Description

The overall Wildlife, Fisheries, and Botany objectives for SRS are to attain viable populations of the Threatened and Endangered species native to the SRS. The program includes habitat and animal surveys to keep accurate records on monitoring populations as well as habitat of the Threatened and Endangered species. The program also entails management and monitoring of "sensitive" species, those species in which viability is a concern. This includes plant and animal species which are candidate species and those species which are of concern to the State Wildlife Department and Heritage Trust. The program endeavors to support a viable population of the Red-Cockaded Woodpecker (RCW), which involves restoration of longleaf ecosystems. Another program includes restoration of Carolina bays, which affect the habitat of many sensitive species. The department works to maintain bald eagle nesting areas as well as forage sites for the Woodstork. Lastly, the department is actively involved in maintaining and increasing the population of Echanacea lapvigata, Smooth Purple Coneflower.

\section{Organizational Responsibility}

The Wildlife Section is responsible for the management of wildlife, fisheries, and botanical plants including Threatened and Endangered Species and their particular habitats.

\section{Major Milestones Accomplished in FY 93}

- Habitat improvement through mid-story control on 417 acres of RCW habitat

- $\quad$ Placement of fifty artificial RCW cavity inserts

- Translocating three juvenile female RCW's

- Increased the RCW population to fifty-three birds

- Restored hydrology to a Carolina bay

- Identified sixty-two new rare plant locations

- Had two successful bald eagle nests 


\section{Major Milestones for FY 94}

- Improvement to habitat through midstory treatment on 300 acres of RCW habitat; also coordinate longleaf restoration and the reintroduction of wiregrass with RCW recovery

- Translocate three RCW juveniles from off-Site and move two birds within-Site

- Increase the RCW population to about sixty birds and fifteen active clusters

- Restore another Carolina Bay

- Increase the population of Smooth Purple Coneflower to 250 plants

\section{Major Milestones for FY 95-99}

- Have thirty active RCW clusters including about 100 birds

- Restore one or two Carolina Bays per year

- Increase the Smooth Purple Coneflower to 300 - 500 plants

- Have three successful bald eagle nests 


\title{
Natural Resource Management
}

Timber

\author{
Program Coordinator
}

Bob Harllee

\section{Program Description}

Manages the forested areas on the Savannah River Site to maintain a healthy and vigorous forest, while providing a sustainable timber supply.

\section{Organizational Responsibility}

Timber prescriptions, timber marking, timber sale appraisals, timber sale administration, site preparation, and reforestation. Also included is timber stand improvement, seed production and genetics program for pine and hardwoods, kudzu control, salvaging diseased timber, thinning stands, and removal of timber as needed for construction and reasearch.

\section{Major Milestones Accomplished in FY 93}

- Red-Cockaded Woodpecker (RCW) thinning of 1935 acres

- Nine compartment prescriptions completed for management of natural resources

- Converted 1573 acres from off-site slash pine to longleaf pine for RCW habitat needs

- Converted 25 acres from loblolly pine to bottomland hardwoods 


\section{Major Milestones for FY 94}

- RCW thinning of approximately 1500 acres

- Fabrication of Feller-Buncher attachment to apply a substance to eradicate the disease Annosus root rot

- Prepare nine compartment prescriptions for management of natural resources

- Convert approximately 1600 acres of off site pines to longleaf pine for RCW habitat

- Convert 54 acres to hardwoods

\section{Major Milestones for FY 95-99}

- More RCW thinning

- Prepare seven to nine compartment prescriptions yearly for management of natural resources

- Continue converting off site pine to longleaf pine and hardwoods 


\section{Natural Resource Management}

Soil, Water and Air

\section{Program Coordinator}

Gary Sick

\section{Program Description}

Savannah River Forest Station is responsible for planning and directing the soil, water, and air resource programs to manage non-point source impacts resulting from natural resource management and secondary road management activities. SRFS also served as technical expert and advisor to other Site organizations for erosion and sediment control, best management practice interpretation and implementation, and comprehensive watershed planning. Finally, SRFS completes erosion control project work as needed to aid other Site organizations.

\section{Organizational Responsibility}

Savannah River Forest Station is responsible for: incorporation of Presidential policy of "no net wetlands loss"; management of SRS soil, water and air resources to enhance quality and productivity; keeping of inventory of SRS water resources; provision of advice on water quality impacts; stabilization of eroding soils as requested; and provision of expert technical advice.

\section{Major Milestones Accomplished in FY 93}

- Completed phase I of two comprehensive watershed plans

- Restored over 210 acres of severely eroding land

- Maintained over 2500 acres of previously restored land

- Planted over seventy acres of hardwoods

- Presented seven workshops to all Site organizations on a variety of conservation topics 
Major Milestones for FY 94

- Complete phase II of two comprehensive watershed plans

- Restore 200 acres of eroding land

- Maintain 2500 acres of restored land

- Present six conservation workshops

Major Milestones for FY 95-99

- Restore 600 acres (total)

- Complete comprehensive plans for entire Site

- Maintain all acres on five year cycles 


\section{Natural Resource Management}

\section{Forest Management Research and Research Support}

\section{Program Coordinator}

John Blake

\section{Program Description}

Research to support SRS land use planning and management of Red Cockaded Woodpecker (RCW) recovery program, restoration/mitigation of Pen Branch corridor and Delta, biodiversity, fuelwood biomass commercialization and operations management such as forest disease control and technology for forest management.

\section{Organizational Responsibility}

Savannah River Forest Station provides research support liason and management oversight for the program. Southeastern Forest Experiment Station conducts research projects in cooperation with universities and provides technology transfer.

\section{Major Milestones Accomplished in FY 93}

- First year of foraging studies completed for RCW

- First year planting of Pen Branch completed

- Migratory bird study started

- Technology transfer studies on longleaf completed

\section{Major Milestones for FY 94}

- Iniitial large field trials on Coarse Woody Debris

- Complete second year Pen Branch Burning and Planting

- Start foames annosum technology development

- Herbicide dissipation complete trials

- Formal review of research programs

Major Milestones for FY 95-99

- Complete Pen Branch project

- Complete RCW foraging research

- Initiate ecological studies of fuelwood biomass plantings 


\title{
Natural Resource Management
}

\author{
Wildland Fire Management Program
}

\section{Program Coordinator}

Patrick O'Bannon

\section{Program Description}

The wildland fire management program's primary objective is to protect SRS facilities, improvements and natrual resources from damaging wildfires. Specific fire suppression goals are to control $91 \%$ of all SRS wildfires at 10 acres or less and $99 \%$ of the remaining SRS wildfires at 100 acres or less.

To meet this goal the SRFS fire management program includes five program elements. (1) Presuppression: involves the planning, budgeting, training and preparedness of personnel and equipment to respond to and suppress any wildfire on the SRS, or any fire threatening the SRS from other ownerships. (2) Detection: deals with early discovery and reporting of wildfires. This is accomplished from fixed detection points including three on-Site fire towers and one off-Site fire tower. The SRFS maintains an aerial detection contract shared with the Francis Marion \& Sumter National Forests to supplement the fire towers as needed. (3) Prescribed fire: requires the careful planning of predetermined units of land to be burned under specific weather parameters. Annually the SRFS control burns some 15,000 acres. This program is key in reducing understory fuels which sustain and contribute to the intensity of wildfires. Prescribed fire is also used to enhance wildlife habitat and is an essential tool in maintaining critical habitat for many endangered or threatened plants and animals. (4) Prevention program goals: to reduce the occurrence of person-caused fires through education and information on safe fire practices in the wildland and urban interface. (5) Fire Suppression: the SRFS fire suppression mission is to fight fire aggressively but provide for safety first.

\section{Organizational Responsibility}

The fire management organization is responsible for the protection of life, property and natural resources threatened by wildland fires, and to improve a variety of forest resources through the use of prescribed fire. 


\section{Major Milestones Accomplished in FY 93}

- Prescribed burned 17,513 acres

- Responded to 21 wildland fires which burned 43 acres on the SRS

- Purchased and installed one remote automated weather station

- Contracted the staffing of Hawthorne and Cassels fire towers

- Completed an agreement with the U.S. Fish \& Wildlife Service for the use of their agency helicopter for aerial ignition for the understory prescribed burning program

\section{Major Milestones for FY 94}

- Prescribe Burn $15,000+$ acres

- Advertise and fill remaining vacant fire positions

- Plan and carry out Smokey Bear 50th celebration probram

- Update the SRFS fire management program analylsis

- Establish a second wildland fire station

- Complete the Southeastern wildland engine training program

\section{Major Milestones for FY 95-99}

- Through a cost analysis, determine the most effective means of fire detection, fixed detection vs. aerial detection

- Increase prescribed burning to 20,000 acres through extended burning season

- Update the fire management operation plan

- Establish a viable growing season prescribed burning program

- Complete a fire management program monitoring plan 
U. S. SOIL CONSERVATION SERVICE, (SCS) ENVIRONMENTAL SUMMARY

\section{Mission}

The Soil Conservation Service is an agency of the United States Department of Agriculture. Our mission is to provide leadership and administer programs to help people conserve, improve, and sustain our natural resources and environment. Activities on the Savannah River Site include natural resource management planning on an ecosystem or watershed basis, wetland protection, erosion and sediment control, soils mapping and soil survey maintenance.

\section{Vision}

The Soil Conservation Service's vision is a productive nation in harmony with a quality environment.

\section{Lead Environmental Coordinator}

Bobby D. McGee

\section{Environmental Accomplishments}

The Soil Conservation Service environmental programs, such as resource planning, watershed planning, soil surveys, erosion and sediment control plan review and development, and critical area stabilization plans provided resource planning assistance on over 2000 acres of SRS lands and assisted in the conservation application treatment to over 1200 acres of SRS lands in 1993 in cooperation with WSRC and SRFS. Technical reviews for resource management and erosion and sediment control management were completed on 68 proposed activities involving land use changes and disturbances during 1993.

\section{Environmental Planning}

The Soil Conservation Service provides technical advise and overview to SRS land users related to the conservation and management of SRS soil and water resources. Activities include developing resource management plans and critical area stabilization plans for specific projects; providing interpretations of the SRS soil survey; providing technical advise on erosion and sediment control issues; providing technical reviews of erosion, sediment and stormwater management plans; conducting resource inventories and assessments. SCS 
environmental programs and plans are described in the following planning documents: annual plan of operations for SRS conservation office, natural resource conservation plan, and scope of work.

\section{Environmental Challenges \& Issues from Projected Mission Changes during Next Five Years}

* Increased emphasis on ecosystem or watershed planning for resource management

* More stringent environmental laws and regulations. 


\title{
Natural Resource Management
}

\author{
Soil and Water Conservation
}

Program Coordinator

Bobby D. McGee

\section{Program Description}

Soil Conservation Service is responsible for providing technical advise and technical overview to SRS on the conservation and management of the SRS soil and water resources. The Soil Conservation Service serves as the expert technical advisor to all site organizations for soils, erosion and sediment control, watershed planning, and best management practices selection. Soil Conservation Service works closely with Savannah River Forest Station and others to complete erosion control work and sediment reduction on the site and to improve water quality.

\section{Organizational Responsibility}

Soil Conservation Service's responsibilities include: developing erosion, sediment and stormwater management plans; review erosion, sediment and stormwater management plans; provide detailed sediment, erosion and stormwater management plans; conduct resource inventories; provide training in the use of and maintenance and interpretation of SRS soil survey; coordinate in the development of wetland inventory; provide technical assistance and training on erosion, sediment control and stormwater management; develop a complete conservation resource plan for hydrologic units; develop critical area stabilization plans.

\section{Major Milestones Accomplished in FY 93}

* Completed first comprehensive watershed plan

* Resource planning assistance provided to site organizations on over 2000 acres

* Technical reviews on 68 resource management and erosion and sediment control plans completed

* Presented 7 workshops to all site organizations on a variety of resource management topics

\section{Major Milestones for FY 94}

* Complete several comprehensive watershed plans

* Present six conservation workshops

* Develop resource management plan for 2000 acres 


\section{Major Milestones for FY 95-99}

* Complete comprehensive watershed plans for entire site.

* Restore old critical eroding sites.

* Improve water quality on surface water streams by reducing all sediment movements into streams.

* Improve wetland management and increase wetland restoration on site. 


\section{Wackenhut Services, Incorporated - Savannah River Site (WSI-SRS) Environmental Summary}

\section{Mission}

The mission of WSI-SRS is to protect Savannah River Site nuclear weapons materials, production facilities, property and classified matter from theft, sabotage, or unauthorized control. WSI-SRS conducts these varied mission responsibilities with a constant concern for protecting the health, welfare and safety of employees, the public, and preserving our natural environment.

\section{Vision}

WSI-SRS's vision is to be recognized as the leader among security contractors in the Department of Energy community. Our customers will recognize us as a caring, responsible, responsive, no-nonsense, safety and environmentally conscious organization.

\section{Lead Environmental Coordinator}

D. R. Beshirs

\section{Environmental Coordinator}

\section{Eubanks}

\section{Environmental Accomplishments}

The WSI-SRS Environment, Safety and Health (ESH) Department was elevated to a Directorate level organization, having direct report status to the General Manager. the new Division is composed of two Departments; the Occupational Safety and Health Department, and the Environmental Protection Department. This re-organization was accomplished, in part, to place increased emphasis on the environmental protection program, and to allow for clear delineation of programmatic responsibilities and increased participation in all areas of environmental protection. Staffing levels were increased to provide WSI-SRS with improved guidance and oversight necessary to develop and maintain successful environmental programs.

WSI-SRS has undertaken several initiatives for improving environmental awareness among employees such as coordinating with 
the WSI-SRS Training Division to include environmental topics in employee training schedules, and by instituting a comprehensive selfassessment program to periodically evaluate the adequacy of environmental protection programs.

\section{Environmental Planning}

Environmental programs and plans are described in the WSI-SRS Environmental Protection Program.

\section{Environmental Challenges and Issues from Projected Mission Changes during the Next Five Years}

Environmental challenges identified for WSI-SRS include:

Pursuit of a DOE approved nonhazardous substitute for the lead ammunition used by the protective force members for practice and qualification.

Removal of lead contamination from the firing range berms.

Continued education of employees on environmental issues.

A reduction in, or elimination of hazardous waste streams.

Increased participation in site environmental programs. 


\section{Engineering \& Projects Division Environmental Summary}

\section{Department}

Construction Management(CM)

Mission

To provide our customers with Construction forces, methods, procedures, and programs that produce safe, high-quality, environmentally sound results that meet or exceed our customer's requirements and expectations; to exist only to serve our customer.

\section{Vision}

To achieve total customer satisfaction through cost-effective processes and efficient performance of every task, to maintain safety, to produce the desired quality, and to continuously improve.

\section{Lead Environmental Coordinator}

S. A. Harvey

Environmental challenges and issues from projected mission changes during next five years:

Construction Management will continue to strive to meet or exceed our customer's requirements and expectations and continue to serve as a center of technical excellence for Construction. 


\title{
Natural Resource Protection, Surface Water \& Wetlands
}

NPDES Outfalls

\author{
Program Coordinator
}

S. A. Harvey

Program Description

Construction Management (CM) has two outfalls, CS-002 in Central Shops and DW002 in S Area. CM plans to stop cleanup/industrial process effluent through the oil/water separator and subsequent discharges to DW-002 when a new facility is established in Central Shops. CM has submitted a project to obtain funding for this heavy equipment wash facility and oil/ water separator. CM has administratively closed the S-Area Batch Plant Pond (SCHEC permit \#10,955) and also the adjoining outfall DW-001. These outfalls are sampled by the EMS and analyzed for compliance parameters.

\section{Organizational Responsibility}

Maintain compliance with SCHDEC permit requirements, and perform routine maintenance at the outfalls on an as needed basis.

\section{Major Milestones for FY 93}

CM has proposed a formal closure of the S-Area batch plant pond which would eliminate the adjoining outfall DW-001. CM plans on moving all steam cleaning operations to Central Shops. This would centralize all process effluent where it would enter a closed loop oil/water separator system and eliminate the need for waste water outfalls CS-002 and DW-002. 
NPDES: S-Area Batch Plant Pond

\section{Program Coordinator}

\section{S. A. Harvey}

\section{Program Description}

The concrete batch plant, installed and permitted to facilitate the batching of concrete for DWPF, has been demobilized. The effluent water from truck washing was clarified and its $\mathrm{pH}$ adjusted in the batch plant's treatment facility prior to release to onsite streams. This Batch Plant Pond is currently under review for formal closure.

\section{Major Milestones Accomplished in FY 92}

CM has submitted a formal closure plan to the WSRC-EPD. Representative samples of the sediment and pond liner have been taken by the Waste Analysis Group and analyzed by an offsite laboratory. Sample results have been submitted to EPD and closure guidance is pending.

\section{Major Milestones for FY 93}

$\mathrm{CM}$ plans to formally close the Batch Plant Pond and restore the area to its original condition. This would eliminate a waste water treatment facility permit and the associated NPDES outfall DW-001. 


\title{
Groundwater Protection
}

\section{Underground Storage Tanks (UST)}

\section{Program Coordinator}

\author{
S. A. Harvey
}

\section{Program Description}

CM plans to install four aboveground fuel storage tanks at Central Shops. The total tank capacity will be 40,000 gallons (30,000 diesel fuel, 10,000 gasoline). This is the first project on site to utilize a concrete encased carbon steel tank which meets the requirements of secondary containment. This system also incorporates a recirculating system for capturing hazardous vapors, thus minimizing the amount of VOCs, which would normally be released to the atmosphere.

\section{Major Milestones Accomplished in FY 92}

Four aboveground storage tanks have been delivered to the site in December 1992. This breakthrough design in fuel storage tanks has become the model for bulk fuel handling at SRS as WSRC plans to modify their bulk fuel handling system to match BSRI which will also provide compatibility. This project sets a new standard of excellence for the site and the environmental gains are expected to be widely publicized.

\section{Major Milestones for FY 93}

The expected construction completion date for aboveground fuel storage tanks is March 1993.

\section{Major Milestones for FY 94-98}

$\mathrm{CM}$ plans to abandon the existing underground storage tanks located at $715-1 \mathrm{~N}$ in Central Shops. CM also, in conjunction with SRTC, will develop a plan to remediate the petroleum contaminated soil in all affected areas. 


\section{Waste Management \& Disposal}

Waste Minimization: Silver Recovery

Program Coordinator

S. A. Harvey

Program Description

The recovery system will reclaim silver from silver fixative that is generated through the film developing process. This will eliminate a hazardous waste stream and recover precious metals for transfer to the Department of Defense.

\section{Major Milestones for FY 93}

CM plans to install a silver recovery unit in Central Shops. CM is working in conjunction with the Power Department to assure all necessary permits are in place to discharge effluent into the sanitary sewer.

\section{Major Milestones for FY 94-98}

CM plans to reclaim silver from a batch process and intends to eventually accept silver fixative form other WSRC entities and subcontractors. 


\section{Waste Minimization: Wood Chipper}

\section{Program Coordinator}

S. A. Harvey

\section{Program Description}

$\mathrm{CM}$ has procured a wood chipper to aid in waste minimization efforts. It will minimize the number of controlled burns at the Central Shops Burn Pit and reduce the amount of land clearing debris entering the Burma Road Landfill. The chipper will also provide a disposal method for pressure treated lumber, creosote treated material and allow $\mathrm{CM}$ to crush and re-use asphalt.

\section{Major Milestones Accomplished in FY 92}

CM procured the wood chipper and it was delivered to SRS in December 1992. CM also began collecting the necessary data to prepare the required SCHEC Air permit needed to process pressure treated and cresote-treated wood products and asphalt.

\section{Major Milestones for FY 93}

CM will only chip regular excess/scrap wood and land clearing debris until the SCDHEC Air Quality Control permit is received. These chips will be used as mulch and for landscaping on site. After receiving the permit $\mathrm{CM}$ plans to also chip pressure treated excess/scrap lumber, creosote treated wood and spoil asphalt. CM is working in conjunction with the Power Department on using the creosote treated wood as fuel in the site powerhouses.

\section{Major Milestones for FY 94-98}

CM plans to accept permitted materials from other WSRC organizations and subcontractors, thereby minimizing landfill space, stockpiling and controlled burns sitewide. 


\title{
Waste Minimization: Lathe Coolant Recovery System
}

\author{
Program Coordinator
}

S. A. Harvey

\section{Program Description}

$\mathrm{CM}$ has procured a lathe coolant recovery system which will recycle the coolant used in fabrication and machine shops where cutting, grinding or drilling takes place. Although the coolant is not hazardous, it is a liquid waste which currently cannot be disposed of on site. CM projects the recovery of the coolant to not only be a best management practice, but also a substantial waste disposal cost avoidance.

\section{Major Milestones Accomplished in FY 92}

The lathe coolant recovery system was procured in 1992. Procedures have been established and are in place on Lathe Coolant Recycling.

\section{Major Milestones for FY 93}

CM plans to set up the recovery system and begin recycling activities in 1993.

\section{Major Milestones for FY 94-98}

CM could possibly accept used lathe coolant from CSWE and other works engineering departments which operate machinery. 


\section{Waste Minimization: Solvent Distillation Units}

Program Coordinator

S. A. Harvey

\section{Program Description}

CM currently operates two solvent distillation units. These units recycle used solvent, mainly from painting activities, into a usable product through a heating/condensation process. Solvent was CM's largest waste stream and the distillation units allowed CM to minimize the hazardous waste by approximately $80 \%$.

\section{Major Milestones Accomplished in FY 92}

CM has received permits from SCDHEC to construct three additional units which will greatly increase the amount and types of solvent that can be reclaimed.

\section{Major Milestones for FY 93}

CM plans to expand the existing solvent recovery facility in order to operate the three additional solvent distillation units. A GPP Project has been submitted for approval to obtain the necessary funds.

\section{Major Milestones for FY 94-98}

With the operation of five distillation units, CM plans to accept used solvent from other site wide organizations in order to promote waste minimization throughout SRS. 
Waste Management: H-Area Inert Waste Landfill

Program Coordinator

- S. A. Harvey

\section{Program Description}

The H-Area Inert Waste Landfill was established in 1984 and permitted by SCDHEC to accept inert construction material. Since that time the landfill has reached its maximum capacity and CM has administratively closed the area. The Burma Road Landfill has been established to accept inert waste materials, and $\mathrm{CM}$ is developing a formal closure plan and trying to appropriate funding to close the H-Area Landfill.

\section{Major Milestones Accomplished in FY 92}

CM submitted a formal closure plan to the WSRC-EPD and a GPP project has been submitted to WSRC Financial Controls to obtain funding for the closure.

\section{Major Milestones for FY 93}

CM plans to begin formal closure of the H-Area Landfill and restore the area to its original condition. 


\section{High Level Waste Division Environmental Summary}

Department

Defense Waste Processing Facility (DWPF)

Mission

To provide environmental support to our customers in a way that is value-added, environmentally responsible and protects the health and safety of all employees.

Vision

To be recognized as the value-added leader in environmental regulatory compliance matters in a way that lends excellence in support of our customers' facilities and processes.

\section{Lead Environmental Coordinator}

R. K. Cauthen 


\title{
Safe Drinking Water Act Program
}

Domestic Water Systems

\author{
Program Coordinator
}

Johnny R. Price

\section{Program Description}

The DWPF domestic water system is the only water system at SRS which is independently owned and operated by area custodians, not the Water Services Department. The system consists of two 1,000 gpm deep wells, a treatment facility, a 15,000 gallon treated distribuion storage tank and transfer lines supplying $S$ and $Z$ Area users. A Back-up Well equippemd with a 3,000 gallon hydropneumatic storage tank is also tied into the sysmiff. The domestic system is ran by DWPF Certified Domestic Water Operators.

\section{Major Milestones Accomplished in FY93}

- Performed sitewide cross connection control survey with WSD.

- Assisted WSRC Site Services Engineering towards developing and integrating the DWPF system with the proposed SRS Consolidated Domestic Water System.

- Perfored Annual Chemical Testing - no deficiencies were noted.

- Implementted the Lead and Copper sampling program.

- Obtained the Construction Permit to tie-in the 221-S Lab Trailers.

- Regained funding to construct domestic and sanitary tie-ins for the 704-49S Training Complex.

- Performed successful bacteriological sampling for the year.

- Performed successful chemical VOC monitoring for the year.

- Received no specific deficiencies requiring SCDHEC follow-up or notification.

\section{Major Milestones for FY94}

- Continue successful compliance sampling for lead and copper.

- Continue to engage in sitewide consolidation doemstic water plans.

- Obtain SCDHEC domestic water permits for new facilities as needed.

\section{Major Milestones for FY95-99}

- Continue to meet all Primary Drinking Water Regulation Standards.

- Lead DWPF efforts to merge with the Sitewide Consolidation plan.

- Obtain domestic water permits for the following projects: Latewash, GWSB, Entry Conrol Facility and the new Administration Building. 
Chemical Management, Pollution Prevention, and other Compliance Programs

\author{
National Environmental Policy Act (NEPA) \\ Program Coordinator \\ Clarke A. Stanford \\ Program Description
}

The National Environmental Policy Act (NEPA) as specified in 10CFR Part 1021 and DOE Regulations establishes responsibilities and requirements for preparation and use of the Environmental Evaluation Checklist (EEC). The intent of the EEC is to ensure that proper Federal and State permits are identified and subsequently obtained.

Major Milestones Accomplished in FY93

- Identified and trained area NEPA coordinators to review, screen and file EEC's applicable to DWPF.

- Assisted in the preparation of instruction/guidance procedures for full implementation of 3Q ECM 5.1 procedure via DWPF' Conduct of Technical Procedure 10.02 and E7 Manual.

Major Milestones for FY94

- Update/manintain Categorical Exclusion (CX) data base on a day to day basis and provide monthly reporting to site NEPA.

- Continue to orient EEC preparers on applicable procedures and establish formal lines of communications.

Major Milestones for FY95-99

Document and maintain an effective screening, preparation and review of EEC's for all area work action requests. 


\section{Natural Resource Protection, Surface Water \& Wetlands}

\section{NPDES}

(Industrial Wastē Water Treatment)

\section{Program Coordinator}

Bharat Damani

Program Description

Develop, organize, lead and coordinate the activities related to the construction and operational permit (application/approval) from SCDHEC on DWPF vitrification and chemical treatment facility.

\section{Major Milestones Accomplished in FY93}

- Obtained operating permit for the Interarea transfer line and LPPP facility.

- Obtained construction permit for APP Bypass of the interarea line.

- Secure DHEC approval on cold chemical run Addendum Rev.2 and temporary modification of ETF for treatment of CCR recycle waste water.

- Developed guide lines on the disposal of DWPF non routine waste water.

- Obtained construction permit for Hydrogen and Ammonia scrubber modification.

- Obtained construction permit for Late Wash Project .

\section{Major Milestones for FY94}

- Obtain DHEC approval on modifications to the operating permit for the tank farm and /or vitrification facility for the following:

- Hydrogen scrubber modification

- Inner area transfer line

- Obtain DHEC approval on the on-site (ETF)or off-site treatment and disposal (POTW) facility for DWPF cold chemical runs aqueous recycie waste stream

- $\quad$ from Melter heatup runs and DWPF Lab waste stream.

- Perform Environmental Readiness self assessment for Melter heatup runs.

\section{Major Milestones for FY95-99}

- Secure DHEC permit to operate the vitrification facility for the following:

- The new late wash systems 


\section{Natural Resource Protection, Surface Water \& Wetlands}

\section{NPDES}

\section{Program Coordinator}

Johnny Price

\section{Program Description}

DWPF releases treated effluent from the Chemical Waste Treatment Facility, Clean Condensate Tank and Cooling Tower to the NPDES DW-4 Outfall. The outfall discharges to McQueen's Branch, a tributary of Upper Three Runs Creek and then to the Savannah River. The Site Environmental Monitoring Section performs monthly compliance sampling.

\section{Major Milestones Accomplished in FY93}

- Obtained NPDES permit renewal for the DW-4 Outfall.

- Pressed for SCDHEC approval to discharge higher limits of Biocide in the DWPF waste process based on chronic criteria of the vendor's test for SCDHEC criteria on toxic control strategies.

- Successfully met the criteria requirements identified in the Site and DOE Headquarters ORR checklists without significant findings for corrective action.

- Developed the DWPF Pollution Prevention Plan (PPP).

\section{Major Milestones for FY94}

- Obtain SCDHEC approval to discharge higher biocide concentrations in DWPF's waste water based on the vendor's test results and the site sponsored biological study.

- Fully implement the DWPF Pollution Preention Plan program. Expand DWPF -PPP Team member roles.. Began performing documented PPP quarterly stormwater inspections.

- Document all SPCC and BMP activities to include in the next facility update.

Major Milestones for FY95-99

- Prepare NPDES outfall permit renewal applications.

- Improve documentation evidence to demonstrate NPDES Outfall compliance

- Develop a comprehensive post management sedimentation and erosion control plan aimed at improving $S$ and $Z$-Area sedimentation basin capacities.

- Reduce erosion and sedimentation of the soil by implementing storm water management and erosion/sedimentation control plan. 


\title{
Natural Resource Protection, Surface Water \& Wetlands
}

\author{
Waste Treatment Facilities
}

\section{Program Coordinator}

Johnny R. Price

Program Description

The S-Area Sanitary Waste Treatement Facility and Sewer Collection System is owned by DWPF but operated by the Water Services Department. The plant includes an influent lift station, an equalization basin, two $12,000 \mathrm{gpd}$ packaged treatment plants and an effluent collection box which dicharges treated sanitary effluent to the Water Services Department NPDES DW-3 Outfall.

\section{Major Milestones Accomplished in FY93}

- Obtained SCDHEC approval to cancel the S-Area Sanitary Expansion Facility Upgrade in favor of near term future connection to the SRS Consolidated Wastewater Treatment Facility.

- Began Construction of the 704-49S lift station tie-in project.

- Coordinated with Site Services Engineering to ensure DWPF is smoothly integrated into the Sitewide Consolidated Wastewater Treatment Facility plans.

\section{Major Milestones for FY94}

- Continue to interface with Site Services Engineering to ensure DWPF is included in construction of the 1.05 MGD centralized SWTP and collection system.

- Complete construction of the 704-49S Lift Station project and receive the final operating permit within the approved permit time frame.

- Apply for new construction permits as needed (Latewash, Entry Control).

\section{Major Milestones for FY95-99}

- Obtain final operating permits for new projects.

- Initiate and complete DWPF sanitary tie-in to the SRS Consolidated Wastewater Treatment Plant.

- Maintain compliance with the three DWPF owned septic tank and tile field systems. 


\section{Groundwater Protection}

\section{Underground Diesel Storage Tanks}

\section{Program Coordinator}

Bharat Damani

\section{Program Description}

Evaluate the existing underground storage tanks for meeting the regulatory compliance and provide recommendation and guidance to the facility operators for their implementation. This includes; 1) evaluating and implementing the SCDHEC and site requirements; 2) performing surveillance on the monitoring and operation requirements; 3 ) reviewing procedures and respond to ORR checklists.

\section{Major Milestones Accomplished in FY93}

- Successfully met DOE Headquarters ORR Checklists items

- Met SCDHEC compliance requirements on the operation and design of underground storage tanks.

\section{Major Milestones for FY94}

- Review the operation of cathodic protection systems and level detection system.

- Implement adequate record keeping requirements.

Major Milestones for FY95-99

Implementation of some of the upgrading requirements of SCDHEC's regulations which apply to DWPF. 


\section{Atmospheric Protection}

\section{Air Emissions}

\section{Program Coordinator}

Ron Reeves

Program Description

Provide regulatory guidance and oversight for all aspects of the CAA which are applicable to DWPF.

Major Milestones Accomplished in FY93

- Obtained air permit to complete the $\mathrm{H} 2 / \mathrm{NH} 3$ modifications to the vitrification process.

- Completed air permit application for the construction of the Late Wash Facility.

Major Milestones for FY94

- Conduct an air emissions inventory update for CY 93 emissions.

- Complete Self Assessment prior to Melter Heatup

- Prepare an action plan for Title V permitting.

Major Milestones for FY95-99

- Obtain CAA Title V permit for DWPF.

- Modify DWPF radioactive sampling devices to comply with 40CFR Part 60, Appendix, Method 1.

- Provide benzene abatement necessary to comply with the 1990 CAA Amendments.

- Phase out usage of CFCs in $\mathrm{A} / \mathrm{C}$ and cooling systems. 


\section{Waste Management \& Disposal}

\section{Z-Area Solid Industrial Waste Disposal}

Program Coordinator

Ron Reeves

\section{Program Description}

Dispose of the Saltstone Waste generated by the Z-Area Wastewater Treatment Facility.

\section{Major Milestones Accomplished in FY93}

- Submitted application to SCDHEC for modification of permit IWP-217 to include design changes for the second generation disposal vaults.

- Entered into negotiations with SCDHEC regarding the Saltstone groundwater monitoring program.

\section{Major Milestones for FY94}

- Obtain modification to permit IWP 217 to include changes incorporated during second generation vault design.

- Conclude negotiations with SCDHEC regarding the Saltstone groundwater monitoring program.

\section{Major Milestones for FY95-99}

- Provide technical/regulatory support for a phased expansion of the Z-Area Industrial Waste Disposal Facility.

- Submit Saltstone closure concept to SCDHEC. 


\title{
Waste Management \& Disposal
}

\author{
RCRA and Waste Management
}

\section{Program Coordinator}

Tim Hagstrom

\section{Program Description}

Provide guidance and permitting assistance where required to insure compliance with and RCRA hazardous waste regulations as they apply to DWPF operations. This includes Hazardous waste accumulation and Organic Waste Storage Tank permit compliance.

\section{Major Milestones Accomplished in FY93}

- Modified Organic Waste Storage Tank Part B application

- Maintained compliance with all hazardous waste staging and satellite areas.

- Produced Quarterly Hazardous Waste Reports and Hazardous Waste Minimization Reports.

- Minimized hazardous waste streams

- Established the Fluorescent Tube collection program for proper disposition of a new hazardous waste stream.

- Assisted in the development of an Operations manual for the Organic Waste Storage Tank.

\section{Major Milestones for FY94}

- Obtain certified laboratory results to allow the removal of the Failed Equipment Storage Vaults from the RCRA Part A permit.

- Minimize hazardous waste streams by reducing volume and/or toxicity

- Provide environmental oversight for startup of the Interim Waste Storage Facility

- Resolve SCDHEC comments of RCRA Part B renewal application for the Organic Waste Storage Tank.

- Provide environmental support for start up of the new laboratory trailer modules.

- Provide environmental support for the Annual Comprehensive Monitoring Ev aluation (CME Audit).

Major Milestones for FY95-98

Tie-in the Organic Waste Storage Tank to the CIF. 


\section{Environmental Implementation Plan}

\section{Program Coordinator}

Clarke A. Stanford

\section{Program Description}

The Environmental Implementation Plan (EIP) program is intended to communicate the current and future (5-year) environmental plans and initiatives from each organization and division that are designed to protect the environment and meet or exceed compliance with changing environmental requirements and laws.

\section{Organizational Responsibility}

Environment Protection Department coordinates the publishing of the Environmental Implementation Plan. DWPF and other site organizations review the site programs and provide their current and future (5-year) environmental plans and initiatives

\section{Major Milestones Accomplished in FY93}

Provided detail input for EIP Summary in 1993.

\section{Major Milestones for FY94}

- Provide detail input for EIP summary report in 1Q94.

- Support objectives in future EIP updates during the calendar year.

\section{Major Milestones for FY95-99}

Continue providing details for all future EIP report updates that apply and relate to DWPF. 


\section{High Level Waste Division Environmental Summary}

Department

High Level Waste Environmental Compliance (HLWEC)

Mission

To provide regulatory support to operating facilities in High Level Waste Management.

\section{Lead Environmental Coordinator}

C. B. Stevens 


\section{Environmental Monitoring}

ALARA

\section{Program Coordinator}

Cassandra Todaro

\section{Program Description}

Coordination and implementation High Level Waste ALARA and Environmental Monitoring Program. Serve as a member of the ALARA Release Guides Committee. Establish and update environmental ALARA release guides for HLW facilities. Ensure that exceedances to ALARA Guides are properly investigated. Review monthly radiation release reports and communicate any unexplained increases to HLW Management. Direct all environmental release reduction efforts and taskteams. Provide support for audits, appraisals and surveillance involving environmental monitoring or the ALARA process. Assisting in the development of facility operating environmental monitoring plans and pre-operational environmental monitoring plans.

\section{Major Milestones for FY94}

- Update and review 1994 ALARA release guides.

- Participate in the updating of the SRS Environmental Monitoring Plan.

- Update, review, and re-evaluate release reduction initiatives as committed in the Environmental Release Prevention \& Control Plan and Air Release Prevention \& Control Plan.

- Work with Engineering and Operations personnel to develop initiatives for eliminating or reducing all radioactive releases to the environment.

- Establish 1995 ALARA release guides.

- Support environmental monitoring or ALARA process audits, appraisals, and surveillances.

Major Milestones for FY95-98

- Establish and update ALARA release guides.

- Update, review, and re-evaluate release reduction initiatives as committed in the Environmental Release Prevention \& Control Plan and Air Release Prevention \& Control Plan.

- Work with Engineering and Operations personnel to develop initiatives for eliminating or reducing all radioactive releases to the environment.

- Support environmental monitoring or ALARA programs audits, appraisals and surveillances. 


\section{Chemical Management, Pollution Prevention, and other Compliance Programs}

Emergency Planning and Community Right-to-Know Act (EPCRA)

Program Coordinator

K. N. Uzochuckwu

Program Description

Coordinate WM SARA III reporting. Participate onsite SARA III subcommittee.

Major Milestones Accomplished in FY93

- Submitted SARA III Usage Report.

- Submit SARA III Toxic Chemical Release Report.

Major Milestones for FY94

- Submitted SARA III Usage Report.

- Submit SARA III Toxic Chemical Release Report.

Major Milestones for FY95-FY99

- Submit SARA III Usage Report.

- Submit SARA III Toxic Chemical Release Report. 


\title{
Chemical Management, Pollution Prevention, and other Compliance Programs
}

\author{
National Environmental Policy Act (NEPA)
}

\author{
Program Coordinator
}

Michael J. Hagenbarth

\section{Program Description}

The National Environmental Policy Act (NEPA) Compliance Program requires that all proposed activities be evaluated to determine if an Environmental Evaluation Checklist must be prepared and approved before the activity may begin.

\section{Major Milestones Accomplished in FY93}

On May 26, 1992, 10 CFR Part 1021 (57 FR 15122, "National Environmental Policy Act Implementing Procedures and Guidelines Revacation: Final Rule and Notice") was implemented. This final rule put DOE compliance with NEPA and related environmental impact assessment factors on a mandatory regulatory basis. At SRS and within HLW, the result of this emphasis is a significant increase in the amount and quality of NEPA documentation, analysis, commitment tracking and mitigation evaluation. A new Department NEPA Coordinator position was created to implement the new requirements in each Department across SRS and the site NEPA procedure $3 Q$ 5.1 , has been revised.

\section{Major Milestones for FY93}

- Support the development of all NEPA documentation required for HLWM facilities (i.e., Environmental Assessments, Environmental Impact Statements).

- Support HLWM Facilities review proposed activities for NEPA concerns.

Major Milestones for FY95-99

- Support the development of all NEPA documentation required for HLWM facilities (i.e., Environmental Assessments, Environmental Impact Statements).

- Support HLWM Facilities review proposed activities for NEPA concerns. 


\section{Natural Resource Protection, Surface Water \& Wetlands}

NPDES: Clean Water Act

\section{Program Coordinator}

K. N. Uzochukwu

\section{Program Description}

Coordinate WM NPDES Program. Coordinate High Level Waste (HLW) preparation and follow-up for the 3560 SCDHEC audit. Provide technical support for the negotiation of the new NPDES permit. Participate on the Site Toxic Control Strategy Team.

\section{Major Milestones Accomplished in FY93}

- Support 3560 audit.

- Coordinate toxicity testing of HLW outfalls.

- Coordinate routine sample analysis.

- Support wastewater permit modification efforts.

- Receive General Permit for stormwater.

- Implement the general permit Stormwater Pollution Prevention Plan.

\section{Major Milestones for FY94}

- Support NPDES permit negotiations.

- Support projects to eliminate toxicity at HLW outfalls.

- Support 3560 audits.

- Support HLW permit modifications.

Major Milestones for FY95-99

- Support projects to eliminate toxicity at HLW outfalls.

- Support 3560 audits.

- Support HLW permit modifications. 


\title{
Natural Resource Protection, Surface Water \& Wetlands
}

\author{
Clean Water Act: WW Permit/FFA
}

\section{Program Coordinator}

M. A Hunter

Program Description

Coordinate HLW Tank Farm Industrial Wastewater permitting efforts and Federal Facility Agreement (FFA) compliance. Coordinate HLW preparation and submittal of regulatory commitments under the FFA and Wastewater permit. Provide technical support for the negotiations of permit modifications.

\section{Major Milestones Accomplished in FY93}

- Federal Facility Agreement signed by EPA, SCDHEC and DOE: $1 / 15 / 93$.

- Industrial Wastewater Permit to Construct issued to HLW Tank Farm: 1/25/93.

- Industrial Wastewater Permit to Operate issued ti HLW Tank Farms: 3/03/93.

- Annual Tank Inspection Report submitted to SCDHEC: 6/29/93.

- Federal Facility Agreement mandated as effective: 8/16/93.

- Tank Removal from Service Schedule/Plan submitted: 11/09/93.

\section{Major Milestones for FY94}

- Submit Annual Update on Progress towards Removal of Tanks from Service: $3 / 16 / 93$.

- Submit Annual Assessment for New/Replacement Tanks and Components: $3 / 16 / 94$.

- $\quad$ Submit Annual Tank Inspection Report: 7/1/94.

- Submit Annual Update of Tank Removal Schedule/Plan: 10/17/94.

\section{Major Milestones for FY95-99}

- Submit Annual Update on Progress towards Removal of Tanks from Service: $3 / 16$.

- Submit Annual Assessment for New/Replacement Tanks and Components: 3/16

- Submit Annual Tank Inspection Report: 7/1.

- Submit Annual Update of Tank Removal Schedule/Plan: 10/17. 


\section{Natural Resource Protection, Surface Water \& Wetlands}

\section{Domestic Water/Sanitary Wastewater Program}

\section{Program Coordinator}

K. N. Uzochukwu

\section{Program Description}

Coordinate High Level Waste Domestic Water and Sanitary Wastewater Program. Provide support and coordination for the domestic water and sanitary wastewater permits (new and modifications). Provide support for domestic water and sanitary wastewater audits and assessments.

\section{Major Milestones for FY94}

- Support domestic water and sanitary wastewater permitting efforts (new and modifications)

- Develop and support domestic water agreement between High Level Waste and Power.

- Develop and issue Operation and Maintenance procedure for Septic Systems.

- Support domestic water and sanitary wastewater audits and assessments.

\section{Major Milestones for FY95-99}

- Support HLW Domestic Water permits (new and modifications).

- Support closure of Septic Systems once CTF is on-line, if necessary.

- Support domestic water and sanitary wastewater audits and assessments. 


\section{Groundwater Protection}

\section{Groundwater Protection}

\section{Program Coordinator}

Laura Bagwell

\section{Program Description}

Provide support for establishing sampling schedules for each well. Establish a program of groundwater monitoring that ensures continued safe operation of High Level Waste facilities.

\section{Major Milestones Accomplished in FY93}

- Began assessing the present groundwater program and made recommendations for improvement.

\section{Major Milestones for FY94}

- Re-test H-Tank Farm wells 5,6,7,8,34, due to unusual Rad levels in first quarter scheduled monitoring.

- Request Gamma PHA, Tritium, Gross Alpha, Non-volatile Beta analyses, in addition to the required analyses for flag $1 \& 2$ for well series FET, FTF, HET, HTF, ZDT, HSE, 241-H in the third quarter of FY 94 sampling period.

- Request formal determinatio by EPD as to the regulatory drivers for the HLW tank farms ground water monitoring program.

- Continue program to ensure adequate sampling for each well.

- Coordinate dry well abandonments, and well improvements process.

\section{Major Milestones for FY95-99}

- Continue to improve groundwater monitoring program within High Level Waste facilities to include the availability of the analytical results database for FY 95 .. 


\section{Atmospheric Protection}

\section{Air Emissions}

\section{Program Coordinator}

David A. Broaden

\section{Program Description}

Provide technical support and coordination to High Level Waste Department (HLW) to ensure compliance with the Clean Air Act (CAA), SARA Title III, and SCDHEC Air Pollution Control Regulations and Standards.

\section{Major Milestones Accomplished in FY93}

- Provided technical support to HLW for annual SCDHEC air emissions compliance inspections.

Major Milestones for FY94 Continue

- Coordinate HLW Title V Permitting effort.

- Provide technical support to HLW on the Phaseout of ozone depleting substances (CFCs and HCFCs).

\section{Major Milestones for FY95-FY99}

- Provide technical support for DOE-SR/ECD Comprehensive Compliance Assurance Reviews (CCARS).

- Provide technical support for annual SCDHEC air emissions compliance inspection.

- Provide technical support for EPA-IV SRS NESHAP's inspection.

- Coordinate WM AEI effort.

- $\quad$ Provide technical support for SARA Title II reporting.

- Provide technical support for CAA and SCDHEC Bureau of Air Quality Control (BAQC) air permitting activities.

- Provide technical support for annual NESHAP's reporting.

- Coordinate HLW Title V Permitting effort.

- Provide technical support to HLW on the Phaseout of ozone depleting substances (CFCs and HCFCs). 


\section{Waste Management \& Disposal}

\section{Resourse Conservation and Recovery Act (RCRA)}

\section{Program Coordinator}

Mike Hagenbarth

\section{Program Description}

Provide technical assistance to HLW facilities in proper classification and management of RCRA hazardous wastes. Provide assistance with preparation and follow-up of annual CME audit. Support HLW facilities in daily compliance issues and activities.

\section{Major Milestones Accomplished in FY93}

- Developed and coordinated implementation of RCRA records program in HLW.

- Supported in preparation and follow-up with CME audit.

- Support annual CME audit.

- Support sitewide program for chemical procurement and use.

- Completed mixed waste inventory report of April 1993 and update of December 1993 for FFCAct.

\section{Major Milestones for FY94}

- Support annual CME audit.

- Support sitewide program for chemical procurement and use.

- Quarterly Hazardous Waste Report

Major Milestones for FY95-99

- Support annual CME audits.

- Complete Quarterly Hazardous Waste reports 


\title{
Comprehensive Environmental Response and Compensation Liability Act (CERCLA)
}

\author{
Program Coordinator
}

Michael J. Hagenbarth

\section{Program Description}

Provide technical assistance to HLW facilities in proper identification and management of CERCLA regulated areas. Provide assistance with preparation and follow-up of CERCLA related reports and audits. Provide assistance in reporting and management of CERCLA Hazardous Substance releases. Support HLW facilities in daily compliance issues and activities.

Major Milestones Accomplished in FY93

- Identified/mapped CERCLA units, as required by the FFA.

Major Milestones for FY94

- Support development and implementation of the On Scene Coordinator (OSC) Contingency Plan \& Operations and Maintenance Plan.

Major Milestones for FY95-99

- Support implementation of the On Scene Coordinator (OSC) Contingency Plan \& Operations and Maintenance Plan within HLW facilities. 


Summary

Department

Separations

Mission

To operate and maintain chemical processing facilities for the production of nuclear materials, primarily related to the defense and security of the country, while maintaining the highest standards of safety, employee treatment, quality, environmental safety and health, safeguards and security, and fiscal responsibility.

Vision

To be recognized by the U. S. Department of Energy and internal customers as the supplier of choice for quality products and services in compliance with regulations.

\section{Lead Environmental Coordinator}

\section{S. J. Robertson}




\title{
Chemical Management, Pollution Prevention, and Other Compliance Programs
}

\author{
National Environmental Policy Act (NEPA)
}

\section{Program Coordinator}

Jeri L. Trickett-Buczek

\section{Program Description}

The Separations NEPA program is operating in accordance with the 3Q ECM 5.1 procedure in compliance with 10 CFR 1021 and 40 CFR Parts 1500-1508. The Plant Modification process implemented at the site level includes environmental review of modifications.

\section{Organizational Responsibility}

The Separations Department NEPA Coordinator is part of a team composed of coordinators from across the site to implement the NEPA process.

\section{Major Milestones Accomplished in FY93}

- Provide support for Separations Operations, Maintenance, and Projects groups in complying with NEPA

- Supported development of EIS for the Upgrade Canyon Exhaust System Project

\section{Major Milestones for FY94}

- Develop EEC training for Separations Engineering personnel

- Support development of EA for HB-Line Phases I and III

- Support development of EIS for Nuclear Material Reprocessing (Operation of F/H Canyons)

Major Milestones for FY95-99

- Support development of EIS for Nuclear Material Reprocessing (Operation of F/H Canyons)

- Provide support for revision of NEPA documents every five (5) years in accordance with 10 CFR 1021.330 


\title{
Chemical Management, Pollution Prevention, and other Compliance Programs
}

\section{Spill Prevention and Control (SPCC)}

\author{
Program Coordinator \\ C. B. Cooper
}

\section{Program Description}

The Separations Environmental Group is on call 24 hours a day to provide support and assistance to Separations in categorizing releases in accordance with the SIRIM system, SRS agreements with SCDHEC, and applicable environmental regulations. The Separations Environmental Group ensures the SEPC is notified, provides guidance to Operations for storage and disposal of clean up materials, and monitors trends of releases in the Separations areas. An internal notification form is completed to collect required information and to document actions.

Operations personnel inspect all SPCC and BMP facilities by procedure on a weekly basis, and informally (no procedure) during rounds made on each shift. The Separations Environmental Group inspects the facilities semi-annually.

\section{Major Milestones Accomplished in FY93}

Determined revisions required for SPCC and BMP Plan updates for Separations Facilities.

\section{Major Milestones for FY94}

Determine, schedule and complete improvements in the Environmental Release Response and Notifications Program for NMPD 200 Areas ES\&H.

Major Milestones for FY95-99

None identified. 


\title{
Natural Resource Protection, Surface Water and Wetlands
}

\section{NPDES}

\author{
Program Coordinator
}

C. B. Cooper

\section{Program Description}

NPDES permitted outfalls F-001, F-002, F-003, F-005, H-004, and $\mathrm{H}-012$ are inspected daily and the $\mathrm{pH}$ is sampled for process control. Monthly compliance sampling and analysis is done by the EMS. All outfalls are inspected by the custodial organization on an informal basis to ensure outfall area is safe, clean, signs current and in place, quality of water appears good, and there is sufficient flow to obtain clean samples. Maintenance orders are in place for Construction to monthly cut weeds, clean pipe grating, clean litter, and perform other minor upkeep at the outfalls.

\section{Major Milestones Accomplished in FY93}

- Updated NPDES permit applications for Separations outfalls. These were submitted to SCDHEC September 1993.

- Received no non-compliances at any of the Separations seven permitted outfalls during the annual and special SCDHEC Compliance Sampling Inspections.

\section{Major Milestones for FY94}

- Perform toxicity identification evaluations on outfalls which do not pass toxicity tests and which may be identified on upcoming permit through an EPD subcontract.

- Investigate feasibility of combining several outfalls to reduce sampling and analysis cost for the site.

- Continue development of erosion control stabilization for Outfall F-001 with the SRS Soil Conservation Service.

\section{Major Milestones for FY95-99}

Perform toxicity identification evaluations under EPD subcontract on remaining Separations outfalls which fail toxicity testing.

Complete project to stabilize erosion problems at Outfall F-001. 


\title{
Waste Management and Disposal
}

Waste Management

\author{
Program Coordinator
}

Gary T. Swisstack, (UST Program: C. B. Cooper)

\section{Program Description}

Facility specific programs for handling RCRA hazardous waste are in place throughout Separations. The programs include facility specific training on hazardous waste and hazardous waste handling, waste specific procedures which are reviewed by knowledgeable SPEG engineers, and quarterly inspections of all hazardous waste satellite and staging areas.

Underground diesel fuel storage tank $(254-5 \mathrm{H} \# 1$ and $2,619-\mathrm{H})$ inventory is measured and recorded daily by Separations Operations personnel. The NMPD 200 Areas ES\&H organization maintains auditable inventory records and performs monthly inventory reconciliation. Tightness testing is conducted by an off-site vendor annually and as required for inventory control purposes. The NMPD 200 Areas ES\&H organization coordinates the testing and provides support to Separations on all underground storage tank regulations.

\section{Organizational Responsibility}

The generator of hazardous waste is required to properly characterize their waste. If a new waste is generated in a Separations facility, the waste is sampled to determine if the waste is hazardous. Each facility has a designated person or group of waste handlers who are trained in the proper handling and storage methods for hazardous waste. All inspections of satellite and staging area are conducted by these people.

\section{Major Milestones Accomplished in FY93}

- Received no hazardous waste handling or storage violations in 1993. The 1993 SCDHEC Compliance Monitoring Evaluation resulted in no major findings against any Separations facility.

- Separations assumed custodianship of three underground diesel fuel storage tanks from Power Department. 


\section{Major Milestones for FY94}

- Provide support to Separations to ensure the automatic tank gauging equipment will function as needed.

- Develop a performance indicator for the length of time hazardous waste is stored in staging areas

- Move the $211-\mathrm{H}$ staging area to a position closer into the $211-\mathrm{H}$ facility.

\section{Major Milestones for FY95-99}

- Upgrade the storage areas as needed.

- Complete closure and/or upgrades to underground diesel fuel storage tanks.

- Aggressively pursue product substitution to eliminate the generation of hazardous waste. 


\section{Waste Management and Disposal}

Waste Minimization

\section{Environmental Challenges \& Issues from Projected Mission Changes during Next Five Years}

Increased emphasis must be placed on Waste Minimization and Pollution Prevention due to the transition of facilities to the Environmental Restoration and Waste Management department within DOE Headquarters. Waste Minimization during D \& D will be a challenge for Separations facilities.

\section{Program Coordinator}

Ed F. Kay

\section{Program Description}

The Separations Program is similar to the SRS Waste Minimization Program. Facility Specific Waste Minimization Plans are the steps to waste minimization within the facilities. Waste Minimization within Separations is done on a prioritized basis, with the major waste streams receiving more of the priorities. Each facility has a waste minimization coordinator who runs the program within their facility. Separations has a program coordinator who ensures that each facility waste minimization coordinator receives the necessary information concerning waste minimization.

Separations has created the Separations Waste Minimization Team which is composed of the Separations Waste Minimization Coordinator and each facility Waste Minimization Coordinator. Resources to the team include management support, a construction representative and a SRTC Representative. The SWMT is tasked to address waste minimization problems within the Separations facilities and to facilitate the exchange of waste minimization information.

Waste Certification is an integral part of waste minimization. Through waste certification, Separations facilities will carefully characterize their waste, and certify that requirements met in the WSRC 1-S Manual, Waste Acceptance Criteria, are met.

\section{Organizational Responsibility}

The responsibility for the $\mathrm{F}$ and $\mathrm{H}$ Separations Waste Minimization Program lies within the SWMT. Each facility manager is responsible to see that waste minimization is accomplished within the respective facility. The Facility Waste Minimization Coordinator assists the facility manager is accomplishing the milestone and objectives set forth in the facility Specific Waste Minimization Plans. 
Major Milestones Accomplished in FY93

- FB-Line became the first site facility to integrate waste minimization into waste certification.

- Separations facilities reduced containerized Low Level Waste generation by $3 \%$.

Major Milestones for FY94

- Implement a Waste Certification Program for all facilities that generate Low Level Solid Radioactive Waste and Mixed Waste by 3/94.

Major Milestones for FY95-99

- Continue Process Waste Assessments 


\section{Atmospheric Protection}

Air Emissions

\section{Program Coordinator}

J. A. McLaughlin

\section{Program Description}

The atmospheric protection program provides environmental support for operations and other activities involving the F\&H Area Separations facilities to ensure compliance with state and federal air regulations. It establishes and maintains programmatic regulatory compliance with the Clean Air Act (CAA).

\section{Organizational Responsibility}

The program coordinator organizes the acquisition and compilation of information to generate reports which must be submitted to EPD for demonstration of regulatory compliance. Each facility manager ensures that the coordinator receives all relevant information for the respective facility.

\section{Major Milestones Accomplished in FY93}

- Completed Action Plan for the prevention and control of airborne radioactive releases for the Environmental ALARA Management Steering Committee

- Completed annual SCDHEC Air compliance inspection of F\&H Area Separations permitted sources.

- Completed annual Air Emissions Inventory for permitted sources.

\section{- Major Milestones for FY94}

- Complete Air Emissions Inventory for facility operations through FY94

- Submit SCDHEC Air Quality Control permit renewal application

\section{Major Milestones for FY95-99}

None identified 


\section{Environmental Restoration}

\section{Program Coordinator}

D. A. Gracy

\section{Program Description}

The 200 Areas ES\&H Environmental Restoration Program was established to support Separations in the transfer of selected facilities into the Site ER Program. It also provides support to $E R$ in the early identification of environmental remediation projects that may be required in the future.

\section{Organizational Responsibility}

The primary responsibilities of Regulatory Programs in the Environmental Restoration Program are as follows:

- Assist in the compilation of data for the characterization of CERCLA waste units.

- Identify the requirements for the collection of additional information such as soil gas surveys, soil borings, well installations, and groundwater analysis.

\section{Major Milestones Accomplished in FY93}

- Completed identification of the areas of past contamination incidents which require Site Evaluations to comply with the recently approved FFA.

- Coordinated the data collection process and assisted in the performance of Site Evaluations.

\section{Major Milestones for FY94}

- Identify the areas of past contamination incidents which require Site Evaluations in 1994 to comply with the recently approved FFA.

- Determine, based upon existing data, what additional data will be required to adequately perform site evaluations in the General Separations Area.

- Coordinate the data collection process and assist in the performance of Site Evaluations.

\section{Major Milestones for FY95-99}

- Identify the areas of past contamination incidents which require Site Evaluations in 1995-99 to comply with the recently approved FFA.

- Coordinate with Environmental Restoration in the design and development of remediation activities for the General Separations Area. 


\title{
Employee Education
}

\section{Environmental Awareness}

\section{Program Coordinator}

\author{
C. B. Cooper
}

\section{Program Description}

The Separations Environmental Group participates on the site wide environmental awareness committee. An Environmental Awareness Day is held in F Area including pamphlets, posters, and displays to educate and inform employees of the environmental activities on site and the many environmental regulations.

\section{Major Milestones Accomplished in FY93}

Coordinated an Environmental Awareness Day by the Separations Environmental Group for F Area. The event was very well attended by personnel in the area.

\section{Major Milestones for FY94}

Participate in Site Environmental Awareness activities.

Major Milestones for FY95-99

None identified. 


\title{
Nuclear Materials Processing Division Environmental Summary
}

\section{Department}

\author{
Tritium
}

Mission

To serve the national security interests of the United States by safely supporting the needs of the Nuclear Weapons Complex while protecting the employee, public health, and the environment.

Vision

To provide only the highest quality product by each individual constantly improving his performance in a team effort to continue our vital role as guardian of the Nuclear Stockpile, the cornerstone of our national defense.

\section{Lead Environmental Coordinator}

Paul Rowan

\section{Environmental Challenges \& Issues from Projected Mission Changes during Next Five Years}

- Operation of building 233-H (RTF).

- Potential shutdown and decommissioning of some process operations in building $234-\mathrm{H}$ (tritium reservoir loading and unloading operations).

- Reduced nuclear weapon stockpile demand as a result of the "peace dividend".

- Consolidation of the Nuclear Weapons Complex with some programs transferred to the Tritium Facilities (SRS). 


\section{Chemical Management, Pollution Prevention, and Other Compliance Programs}

EPCRA, SPCC, BMP, PPP, NEPA

Program Coordinators

Paul Rowan, Brad Wilson and Kevin Sessions.

Program Description

Current and future Tritium Facilities(TF) operations require compliance with EPCRA, SPCC, BMP, PPP and NEPA regulations.

Organizational Responsibility

Tritium Environmental (NMPD ES\&H) assists the Tritium Facilities in complying with EPCRA, SPCC, BMP, PPP, and NEPA requirements. Environmental personnel assist with preparing documentation for these compliance programs. The TF Chemical Coordinator (Robert Rhodes - TSS) provides HAZCOM training to all TF personnel and maintains material safety data sheets (MSDS). The TF NEPA coordinator is Kevin Sessions (NMPD ES\&H)

Major Milestones Accomplished in FY92

- Annual SARA Title III inventory completed on schedule.

- Annual Tier II Chemical Inventory

- HAZCOM training given to TF personnel.

- Spill control pallets procured for liquid wastes (RCRA and non-RCRA) stored outdoors.

- Environmental Evaluation Checklist (EEC) made available on TF electronic desktop. [NEPA]

Major Milestones Accomplished in FY93

- Annual SARA Title III inventory completed on schedule.

- Annual Tier II Chemical Inventory

- HAZCOM training given to TF personnel.

- Tritium Facilities NEPA coordinator (Jill Sessions) appointed. 


\section{Major Milestones Accomplished in FY94}

- Annual SARA Title III inventory completed on schedule.

- Annual Tier II Chemical Inventory

- HAZCOM training given to TF personnel.

- New Tritium Facilities NEPA coordinator (Kevin Sessions) appointed.

- Reviewed and updated TF contribution to SPCC and BMP plans.

\section{Major Milestones for FY95-99}

- Perform annual SARA Title III and Tier II inventories.

- Update and give HAZCOM training to TF personnel.

- Review and update TF contribution to SPCC and BMP plans per EPD request. 


\title{
Natural Resource Protection, Surface Water \& Wetlands
}

NPDES

\author{
Program Coordinator
}

Brad Wilson

\section{Program Description}

Tritium discharges once-through segregated process cooling water and other lowlevel, non-hazardous liquid effluents to tributaries of Upper Three Runs Creek (NPDES Outfall H-002) and Four Mile Creek (NPDES Outfall H-012). These liquid effluents are monitored by Tritium Operations twice a day for tritium concentration. EMS also measures tritium concentration on a weekly or every other week basis depending on the discharge point. Replacement Tritium Facility liquid effluents from their cooling tower and hold volume are also analyzed prior to discharge to site streams.

\section{Organizational Responsibility}

Tritium Environmental (NMPD ES\&H) is responsible for ensuring that the liquid discharges from the Tritium Facilities comply with the Clean Water Act (NPDES).

\section{Major Milestones Accomplished in FY92}

- Participated on the SRS Environmental Release Prevention Task force (ERPT). Developed action items for ensuring that liquid effluents are properly monitored for tritium. All TF-specific action items resolved.

- Developed Tritium Facilities program for sampling the H-002 (HP-15) and H-012 (HP-50) outfalls for tritium concentration. Procedures developed for sampling, analysis, and response to high tritium concentrations.

- RTF erosion control project initiated. Modifications made to RTF sedimentation basin to reduce potential for solids going to the outfall.

- Stormwater discharge routes in the Tritium Facilities walked down. Stormwater discharge permit application made.

- SCDHEC 3560 audit of the NPDES H-002 and H-012 outfalls found no deficiencies.

Major Milestones Accomplished in FY93

- Submitted NPDES permit renewal application for H-002 and H-012 outfalls. 


\section{Major Milestones Accomplished in FY94}

- Annual TF RCRA/Waste Minimization training expanded to include Clean Water Act (CWA) items.

- Radioactive liquid effluent CCAR conducted. No TF deficiencies found.

- Annual SCDHEC 3560 audit of the NPDES H-002 and H-012 outfalls found no deficiencies.

\section{Major Milestones for FY95-99}

- Install continuous tritium monitors at the TF liquid effluent discharge points.

- Potentially relocate H-002 outfall or consolidate it with H-004 outfall.

- Toxicity testing of the H-002 and H-012 outfalls with on-site screening to be determine applicability. 


\section{Waste Management \& Disposal}

Waste Management

Program Coordinators

Brad Wilson

\section{Program Description}

The Tritium Facilities generate various forms of waste to include non-hazardous, hazardous, mixed, and sanitary wastes during normal operations. Procedures and plans have been developed and implemented to ensure environmental compliance, as well as, proper waste management and disposal practices.

\section{Organizational Responsibility}

Tritium Environmental (NMPD ES\&H) provides assistance to ensure Tritium Facilities compliance with applicable waste management regulations (e.g. RCRA). Tritium Environmental personnel also provide technical support and training for various TF waste management activities and disposal practices especially with regard to waste minimization and RCRA compliance.

\section{Major Milestones Accomplished in FY92}

- RCRA training developed and presented to appropriate personnel.

- Waste minimization training developed and presented to appropriate personnel.

- TF waste minimization plan reviewed and revised.

- Non-hazardous, low-level radioactive waste generation reduced 15 percent.

- Practice of reviewing operating procedures for waste minimization applicability initiated.

- Waste minimization information presented in TF update newsletter.

- $4 \mathrm{HW} / \mathrm{MW}$ shipments made to Waste Management.

- All quarterly hazardous waste reports prepared and submitted on schedule.

- Provided a TF interface to the Hazardous Waste/Mixed Waste Treatment Facility project (Title I Design review).

- Supported SCDHEC RCRA CME audit preparation and follow-up.

- Developed schedule for implementation of a Waste Certification Program during FY93-94. 


\section{Major Milestones Accomplished in FY93}

- Prepared for SCDHEC RCRA Compliance Monitoring Evaluation (CME).

- More RCRA and Waste Minimization Training developed and presented.

- Transferred expired/unused chemicals to Construction Sort Yard for use by other SRS work groups.

- Continued implementation of Waste Certification Program milestones.

\section{Major Milestones Accomplished in FY94}

- Contributed TF data to the Mixed Waste Inventory Report (MWIR).

- Developed and signed a Memorandum of Agreement (MOA) between the Tritium Facilities and Reactors for using the L-Area compactor for low-level waste from the Tritium Facilities.

- TF RCRA/Waste Minimization training revised and expanded. Annual RCRA/Waste Minimization training given to appropriate personnel.

- Waste certification plans developed and approved for 233-H and 238-H.

- Tritium Facilities Waste Minimization Plan reviewed and revised.

- Tritium Facilities personnel provided contributions to the SRS Draft Site Treatment Plan for hazardous/mixed waste

- Provided support for resolution of Notice of Violation (NOV) on improper storage and disposal of destructively tested neutron generators.

\section{Major Milestones for FY95-99}

- TF low-level waste compactor installed.

- Complete Waste Certification Program implementation.

- Conduct follow-up PWA on low-level radioactive waste.

- Develop methods for proper disposition of retired/obsolete weapon components. 


\section{Atmospheric Protection}

\section{Air Emissions}

\section{Program Coordinator}

Paul Rowan

\section{Program Description}

Tritium Facilities operations emit tritium to the atmosphere from all TF processing buildings. These atmospheric effluents are sampled and monitored to ensure personnel protection, as well as, state and federal environmental regulatory compliance. Other non-radioactive emissions potentially include asbestos from equipment insulation. HCFCs/CFCs from HVAC systems and degreasing operations, and diesel generator exhaust from permitted sources in the TF.

\section{Organizational Responsibility}

Tritium Environmental (NMPD ES\&H) is responsible for ensuring that the Tritium Facilities complies with the Clean Air Act and any other state or federal regulation designed to protect the atmosphere.

\section{Major Milestones Accomplished in FY92}

- Provided environmental interface/support for Project S-3751, Improved Tritium Stack Samplers and Monitors.

- Asbestos abatement projects on HVAC equipment continues.

- Developed FPR for a project to install isokinetic sampling on the building 232-H, Line III stack.

- Assisted in preparation for the SCDHEC air compliance inspection of two TF permitted sources. Provide TF environmental interface during the inspection.

- Provided TF interface to EPA Region IV NESHAP compliance inspection of TF exhaust stacks.

\section{Major Milestones Accomplished in FY93}

- Completed TF Air Emissions Inventory (EPD and Radian Corporation (subcontractor) assisting).

- Provided TF interface and data for the Action Plan for the prevention and control of radioactive releases for the Environmental ALARA Management Steering Committee.

- Completed asbestos abatement projects .

- Provided air emissions data for SCDHEC air compliance inspection. 
- Completed Project S-3751, Improved Tritium Stack Samplers and Monitors. Evaluate stack monitoring capability and report results to EPA Region IV personnel.

- Provided TF interface for annual EPA Region IV NESHAP compliance inspection of TF exhaust stacks.

\section{Major Milestones Accomplished in FY94}

- Replacement Tritium Facility (Building 233-H) fully operational. Atmospheric releases from reservoir loading and unloading operations reduced.

- Building 234-H reservoir loading and unloading operations end. Lay-up plan developed for putting loading and unloading processes in stand-by mode.

- Performed second annual TF air emissions inventory .

- Provided TF interface for annual EPA Region IV NESHAP compliance inspection of TF exhaust stacks.

\section{Major Milestones for FY95-99}

- Prepare schedule for implementation of HCFC/CFC phaseout in the TF. Determine appropriate substitute materials or actions.

- Develop TF program for maintaining Air Emissions Inventory data.

- Revise air emissions data to reflect potential for reduced tritium emissions as a result of building $233-\mathrm{H}$ assuming all tritium loading and unloading operations.

- Prepare TF applicable Title V air permits. 


\title{
Environmental Restoration Program
}

\author{
Environmental Restoration
}

\section{Program Coordinator}

Paul Rowan

\section{Program Description}

Currently, there are no active environmental restoration projects within the Tritium Facilities. However, preliminary work has been done on characterizing (describing) the abandoned, inactive H-Area seepage basin header (18 inch vitrified clay pipe) located inside the Tritium Facilities fence. No future environmental restoration projects within the Tritium Facilities have been determined.

\section{Organizational Responsibility}

Environmental Restoration (ER) is responsible for any remediation projects on the SRS. Tritium Environmental (NMPD ES\&H) provides technical support and information to ER to aid in their assessments of any abandoned waste sites. EPD also provides assistance in assessment of these abandoned waste sites from a regulatory compliance standpoint.

\section{Major Milestones Accomplished in FY92}

- Repaired leaking abandoned seepage basin header during repair work on Tritium Facilities Entry Control Facility (ECF) vehicle trap. (Assistance by EPD and ER.)

- Made a preliminary characterization of the abandoned, inactive H-Area seepage basin header located inside the Tritium Facilities fence.

\section{Major Milestones Accomplished in FY93 and FY94}

- No significant ER milestones were accomplished during FY93 and FY94 in the Tritium Facilities.

\section{Major Milestones for FY95-99}

- Formally document the characterization on the abandoned seepage basin inside the Tritium Facilities. Locate access points and potential sources of water in leakage. 


\section{Environmental Accomplishments}

Completed removal of underground storage tanks from the 100 areas.

Removed all Aboveground Storage Tanks with the exception of 107-A. 


\title{
Reactor Division Environmental Summary
}

\author{
Department
}

300 Area Environmental Group

\section{Mission}

The mission of the 300-Area Environmental Group is to direct Reactor Materials Department (RM) activities such that environmental regulations and requirements are met and sound environmental practices are promoted.

\section{Vision}

The vision of 300-Area Environmental Group is to set the standard of excellence at the Savannah River Site in the management of environmental activities and programs.

\section{Lead Environmental Coordinator}

\author{
J.C. Musall
}

\section{Environmental Coordinators:}

R.M. Benson

J. V. Burch

G. A. Diener

H.L. Martin

S.W. Norford

A.L. Patterson

J.B. Pickett

\section{Program Area}

Atmospheric Protection

Waste Minimization

Environmental Restoration

NPDES Resource Protection,

Surface Water and Wetlands

Clean Water Act

NEPA

TCLP Compliance

Waste Management 
D.G. Poulos

D.M. Wittry
RCRA Compliance

NPDES Compliance

\section{Environmental Accomplishments}

Awarded first contract for vitrification of a mixed (radioactive/hazardous) waste in the DOE complex. The highly durable wasteform and the low volume of the final product, will substantially reduce the long-term environmental impact of the disposal of the M-Area waste.

Reduced mixed waste generation at the Liquid Effluent Treatment Facility (LETF) over 95\% bv converting the filtration process to filterbelts instead of single pass filter media.

Successfully met several Land Disposal Restriction-Federal Facility Compliance Agreement (LDR-FFCA) milestones for the treatment of mixed waste sludges in tank storage at M-Area.

Successfully met several NESHAPs FFCA milestones for the installation of continuous monitoring equipment at the Fuel Fabrication Facility, Building 321-M.

Completed the treatment of 324,500 gallons of supernate at the LETF, thereby, reducing the volume of hazardous wastewaters stored in M-Area.

Shutdown the Target Fabrication Facility (Building 320-M) in full compliance with all applicable environmental regulations. Successfully, excessed over 123,000 pounds of chemicals material through recycling/reuse which needed removal from the facility. This represented a greater than 3:1 ratio of recyclable/reuseable chemicals/materials to waste generated.

Developed/implemented a SCDHEC-approved method for recycling lead-acid batteries from Radiological Control Areas by treatment of the battery acid at the LETF.

Developed/implemented a pallet substitution method at the Fuel Fabrication Facility. The reuse of steel pallets for transfer of supplies into and out of Radiological Control Areas will eliminate the need to dispose of approximately 1,650 wooden pallets, 28 low-level radioactive waste over the next two years. 


\section{Environmental Planning}

The following documents contain environmental information about out department's programs: Savannah River Site FY 1994 Operating Plan, Environmental Implementation Plan, WSRC-IM93-17, and WSRC FY1995 Outyear Budget and Five Year Plan.

\section{Environmental Challenges and Issues from Projected Mission Changes During the Next Five Years}

Define what role the M-Area Liquid Effluent Treatment Facility (LETF) will have in the treatment of SRS mixed wastes, after completion of the treatment of the M-Area Plating Line Wastes. The challenge of the next five years is to integrate the capabilities of the M-Area LETF into the waste treatment plans required by the Federal Facilities Act of 1992.

Successfully remove process equipment in FY96-98 from M-Area facilities in a cost-effective manner while maintaining compliance with all applicable environmental regulations, and transfer the fully characterized emptied buildings to the Office of Environmental Restoration and Waste Management.

Lead the M-Area/subcontractor efforts to stabilize the M-Area sludges while maintaining compliance with RCRA Land Disposal Restrictions and attaining the aggressive schedule of the LDR-FFCA. 


\title{
Chemical Management, Pollution Prevention, and Other Compliance Programs
}

\author{
EPCRA, OSHA
}

Program Coordinator

Michael Sutton

\section{Program Description}

The 300-Area Chemical Inventories Improvement Plan has been implemented. The M-Area Chemical Inventory System (MCIS) is in the RM support network to provide chemical information and assist chemical custodians to perform chemical inventory. The RM chemical custodian meetings are held monthly.

\section{Organizational Responsibility}

300 Area ES\&H assists the Reactor Materials Facilities in complying with EPCRA. and OSHA requirements. A computerized database (MCIS) to manage the RM chemicals was developed. The database is maintained by facility and 300 Area ES\&H personnel. The program coordinator provides HAZCOM training to the RM chemical custodians and chemical coordinator.

\section{Major Milestones Accomplished in FY93}

- Trained Facility Personnel how to use MCIS

- Assisted Area Chemical Coordinators with Forum R Report to EPA

- The RM Chemical Custodian Meetings were held every month

- The procedure SOP 300-182, Reactor Materials Chemical Inventory and MSDS Availability, was reviewed and/or revised (12/16/1992)

\section{Major Milestones for FY94}

- The information of chemical ingredients, HAZCOM ratings, Blue Dot and other regulated chemical identifications will be added to The MCIS. (3/1994)

- A periodic RM surveillance of the Chemical Inventory program will be implemented beginning April 1994

- A periodic performance indicator of the Chemical Inventory program will be initiated in May 1994.

Major Milestones for FY 95-98

- Review and update MCIS database quarterly.

- Review and update SOP 300-182 every 2 years. 


\title{
Chemical Management, Pollution Prevention, and Other Compliance Programs
}

\author{
National Environmental Policy Act (NEPA)
}

Program Coordinator

Steve Norford

Program Description

The Reactor Materials program is currently operating from the WSRC 3Q ECM 5.1 procedure and the WSRC Implementation Plan for NEPA in compliance with 10 CFR 1021 and 40 CFR Parts 1500 - 1508. No area specific procedures have been developed. The Technical Review consideration/process implemented at the department level includes environmental review of modifications for Nuclear Safety (NS) and Critical Protection (CP) and Production Support (PS) and certain General Services (GS) systems.

Organizational Responsibility

The Reactor Materials Department NEPA coordinator is part of a sitewide team composed to implement the NEPA regulations.

Major Milestones/Accomplishments from FY93

- Implemented WSRC 3Q ECM 5.1 procedure

- Provided support for Reactor Materials Operations, Maintenance, and Projects groups in complying with NEPA

- Re-assessed required NEPA documentation of Project 2700 "Billet Handling"

Major Milestones for FY 94

- Complete Vendor Treatment Process and Storage Pad EA

- Determine/ Complete NEPA requirements for Deinventory of Contaminated Mark 22 Assemblies at Building 321-M

- Consolidate NEPA activities within Reactor Division where applicable.

\section{Major Milestones for FY $95-98$}

- Provide support for revision of NEPA documents every five (5) years in accordance with 10 CFR 1021.330

- Provide NEPA documentation for shutdown/standby activities 


\title{
Natural Resource Protection, Surface Water and Wetlands
}

NPDES

\author{
Program Coordinator \\ G. A. Diener
}

\section{Program Description}

Reactor Materials releases treated effluent from the Dilute Effluent Treatment Facility (DETF) to Outfall M-004 and on to Tims Branch via Outfall A-014. Each process batch is sampled by $R M$ and analyzed by the $320-M$ Laboratory prior to the release to ensure compliance with NPDES permit limits. The Outalls M-004 and A-014 are sampled and analyzed weekly by the Environmental Monitoring (EMS).

\section{Organizational Responsibility}

The Reactor Materials Environmental Group (EG) is responsible for ensuring that the DETF and all its discharges are in compliance with the Clean Water Act.

\section{Major Milestones Accomplished in FY 93}

- Processed 332,467 gallons of supernate during FY 93

- Chronic toxicity testing performed at Outfalls A-014 and M-004 to ensure no harm to the environment

- Submitted NPDES permit renewal application for Outfalls A-014 and M-004 to EPD on November 12, 1992

- Relocated supernate transfer pump to Interim Treatment/Storage Facility (IT/SF) Tank 7 and SCDHEC approved operation on December 30, 1992

- Evaluated Liquid Effluent Treatment Facility (LETF) capacity to treat A-Area powerhouse wastewater

- No Deficiencies found on 3560 Audit in M-Area

- Performed non-destructive testing on all BMP tanks in M-Area

\section{Major Milestones for FY94}

- Finished IT/SF Tank 7 supernate

- Transferred IT/SF Tanks 1-6 supernate to IT/SF Tank 8

- Submitted IT/SF Tank 8 treatability study to SCDHEC

- Relocated supernate transfer pump to IT/SF Tank 8 and SCDHEC approved operation on December 2. 1993

- No deficiencies found on the 3560 Audit in M-Area 
- Notify SCDHEC 90 days prior to last transfer of DETF filter cake from supernate treatment to IT/SF Tanks

- Submit IT/SF Tank 10 supernate treatability study to SCDHEC

- Relocate supernate transfer pump to IT/SF Tank 10

- Complete processing all IT/SF supernate

- Negotiate new NPDES permit conditions and ensure compliance when issued by SCDHEC

- Submit wastewater permit modifications to EPD for the M-Area Vendor Treatment Process

Major Milestones for FY95-98

- Submit wastewater permit modification to treat A-Area powerhouse wastewater. if approved by Change Control Board !

- Relocate A-014 to comply with new permit condition, if required

- Perform Toxicity Reduction Evaluation (TRE), if necessary

- Submit NPDES permit renewal application

- Submit closure plan for the LETF, if necessary

- Divert all stormwater to Outfall M-002 


\title{
Waste Management and Disposal
}

Waste Management

\section{Program Coordinator}

\author{
J. B. Pickett
}

\section{Program Description}

The Reactor Materials Waste Management Program includes the following objectives.

- Manage all hazardous wastes in total compliance with the regulatory requirements (State and Federal).

- Ensure that the RCRA treatment and storage facilities managed by the Reactor Materials Department are operated in full compliance with the regulatory requirements.

- Conduct the M-Area de-inventorying program such that the minimum amounts of hazardous wastes are generated during the lay-up program. by reuse and recycling of any suitable materials.

- Ensure that any hazardous wastes generated by a "shutdown" activity are anticipated, and are managed according to the hazardous waste regulations.

- Minimize the amount of any hazardous waste generated, especially the amounts of mixed waste.

- Minimize the amounts of radioactive/non-hazardous and sanitary wastes generated, in order to preserve the limited landfill capacities.

- Ensure that all wastes are categorized correctly and that the appropriate documentation is maintained.

\section{Major Milestones Accomplished in FY93}

- Completed treatment of 332,500 gallons of supernate from the IT/SF

- Implemented use of new type filter media (reusable belts) in the DETF

- Completed relocation of supernate transfer system to Tank 7 from Tank 8

\section{Major Milestones for FY94}

- Select subcontractor to treat and stabilize the sludge in the M-Area tanks by 12/93

- Implement waste certification for the M-Area Low Level Waste \& Mixed Waste by $12 / 94$

- Submit all necessary permits for Vendor Treatment Program by 6/30/94

- Complete treatment of supernate in from the IT/SF tanks 


\section{Major Milestones for FY95-98}

- Start treatment of M-Area sludge within 225 days of permit approval (estimated 9/95)

- Complete treatment of M-Area sludge by subcontract within twenty months of start of treatment (estimated 5/97)

- Close all M-Area tanks, and complete certification by $3 / 98$

Waste Minimization

\section{Program Coordinator}

\section{J. V. Burch}

\section{Program Description}

The Reactor Materials (RM) waste minimization program is a very aggressive program resulting in the reduction of all types of waste streams. SOP 300-168 (Waste Minimization in Reactor Materials (U)) is the programmatic document which outlines the waste minimization program for RM. As required by this procedure, RM issues annual reports summarizing waste minimization performance in $M$-Area and providing details on future efforts. The annual report fulfills the documentation and reporting requirements found in the RM procedure and the Department of Energy Savannah River Site Waste Minimization Plan Rev 4. The annual report, in conjunction with the waste minimization procedure, meets all of the site's requirements and guidance for facility-specific waste minimization programs and their maintenance.

The RM waste minimization program has made significant progress to reduce the amount of waste that is generated. Waste minimization considerations are included in procedures, job plans, and technical reviews whenever appropriate. In addition, waste minimization has become an integral part of all job responsibilities and projects. Costjustified waste minimization opportunities are then implemented as the opportunities are identified.

RM has established programs for forecasting, tracking, and reporting waste generation and publishes the results in the WSRC Performance Indicator program. In addition, $R M$ issues its own internal performance indicator report on waste generation. $R M$ uses these reports to identify areas in which waste minimization efforts can improve.

\section{Organizational Responsibility}

The Reactor Materials Engineering and Technology Environmental Group (RMET EG) assumes direct responsibility for the reporting requirements associated with RM waste minimization. This group tracks waste minimization in M-Area and ensures all environmental issues associated with waste minimization are resolved.

Along with the RMET EG, the RM Waste Coordinator plays a major role in waste 
minimization. The Waste Coordinator chairs the RM Waste Action Team (RM WAT) which is composed of various personnel from the RM operating facilities.

The RM WAT team members represent all appropriate RM groups including Production. Maintenance. HP, Analytical Laboratories, Quality. Program Integration. and Technical. Overall, the team's mission is to identify, evaluate, initiate, and monitor waste minimization activities, and the team also increases waste minimization awareness in the RM facilities. The RM WAT meets monthly to discuss ideas on waste minimization. to comply with site directives, to be the pro-active voice for waste issues, and to review information from the SRS WAT and Waste Coordinator meetings. Where appropriate, the RM WAT chairman is responsible for defining the applicable Consolidated Labor System (CLS) time codes that are used by personnel for waste minimization activities.

\section{Major Milestones Accomplished in FY93}

- The replacement of disposable filter media (Filter Paper Take Up Rolls) with cleanable filter belts at the DETF

- The treatment of 324,500 gallons of supernate at the Dilute Effluent Treatment Facility (DETF)

- The decrease in low level waste generated by 26 percent in FY93 compared to FY92 generation rates

- The shutdown of processes in Building 320-M

- The awarding of the sludge vitrification contract to an off site vendor

\section{Major Milestones for FY94}

- Completion of supernate treatment at the DETF (450,000 gallons treated)

- Decrease of mixed waste generated by 60 percent as compared to FY 93 generation rates

- Additional decrease in low level waste generated of approximately 10 percent as compared to FY93 generation rates

\section{Major Milestones for FY 95.98}

- Submit delisting petition to EPA for the Used Filter Take Up Roils (UFPTUR) to reclassify the waste from mixed waste to low level waste

- Submit delisting petition to EPA for the vitrified sludge, which will be generated as a result of the M-Area Vendor Treatment Program for 1995-1997 


\section{Atmospheric Protection}

\section{Air Emissions}

\section{Program Coordinators}

R. M. Benson

\section{Program Description}

Taking appropriate measures to ensure that new and existing facilities comply with current regulatory requirements.

\section{Organizational Responsibility}

The 300-Area Environmental Group is responsible for ensuring that all M-Area facilities and all their discharges are in compliance with the Clean Air Act.

\section{Major Milestones Accomplished for FY93}

- Completed Action Plan for the prevention and control of airborne radioactive releases for the Environmental ALARA Management Steering Committee - 3/93

- Exempted the 320-M permitted Diesel Generator - 3/93

- Submitted to SCDHEC Air Emissions Inventory - 9/30/93

- Completed Project S-2972 and submit data to EPA - 12/93

- Upgraded S-2972-6/93

- Developed program to maintain current Air Emissions Inventory - (ongoing)

- Completed Point Source Inventory-3/93

- Began program to determine opacity limits for Diesel Generator- (ongoing)

\section{Major Milestones for FY94}

- Complete FFCA milestone agreement M-Area Permit Renewal

- Tritium monitor additions to 321-M

- Addition of new point source to the M-Area permit

\section{Major Milestones for FY95-98}

- Implement Program Activities as production facilities shut-down, e. g. cap exhaust systems, revise permits, etc. - 12/97

- Maintain facilities permit compliance 


\title{
Environmental Restoration Program
}

\section{Environmental Restoration}

\section{Program Coordinator}

\author{
G. A. Diener
}

\section{Program Description}

Environmental Restoration (ER) has several remediation projects operating in the 3/700 Area. Currently, Reactor Materials is operating two Ground Water Air Strippers to treat groundwater contaminated with solvents; one at the Savannah River Technology Center (SRTC), A-1 air stripper; and one in M-Area, M-l air stripper. Future ER projects include another SRTC air stripper, a southern sector air stripper, and four $\mathrm{A} M \mathrm{M}$ Area vadose zone treatment systems.

The M-1 air stripper discharges to Outfall M-005 and on to Tims Branch via Outfall A-014. The A-1 air stripper discharges to A-001A and on to Tims Branch via Outfall A-1.

\section{Organizational Responsibility}

ER is responsible for ensuring that all remediation projects are in compliance with applicable federal and state regulations. The Reactor Materials Environmental Group is providing project liaison between $\mathrm{RM}$ and ER on all future remediation projects.

\section{Major Milestones for FY93}

- Provided technical support for M-1 and A-1 air strippers

- Provided project liaison for future ER projects

\section{Major Milestones for FY95-98}

- Provide project liaison for future ER projects 


\title{
Savannah River Technology Center Division Environmental Summary
}

\author{
Department
}

SRTC Savannah River Technology Center Environmental (all departments) and Site Services Division's Laboratory Operations and Services Department Summary (Note: SRTC facilities are owned and operated by the Laboratory Operations and Services Department of the Site Service Division. For the remainder of this section of the EIP, the term 'SRTC' will refer to both the Savannah River Technology Center and the Laboratory Operations and Services Department.)

\section{Mission}

The Savannah River Technology Center (SRTC) will support the current and future SRS Mission by providing the technical basis, understanding and advanced capabilities for safe, environmentally sound, high-quality, cost-effective, and continually improving operations.

\section{Vision}

To be highly valued by our customers as a technically excellent, innovative, effective, results-oriented, cost-conscious, technical laboratory that is an essential contributor to fulfilling the SRS Mission and is highly regarded by our employees as fostering an atmosphere of teamwork, safety, environmental stewardship, challenge and continual improvement.

\section{Lead Environmental Coordinator}

Nanicy V. Halverson

\section{Environmental Challenges and Issues from Projected Mission Changes During the Next Five Years}

SRTC functions as an applied research and development center, providing technical support for all the major activities and operating facilities at the SRS. Currently the division provides this research and development for the site through the following major programs:

- conducting research, process development, and technical support for the management of radioactive wastes and environmental issues. 
- providing technical support for chemical separation processes, tritium process development, reactor operations, and manufacture of fuel and target assemblies,

- developing computer codes for use in research and development.

- conducting safety analyses on reactor and nonreactor processing operations, and as the site undergoes changes in its mission in future years, the SRTC mission will change to provide technical support, research and development on new site initiatives.

\section{Environmental Coordinators}

$\underline{\text { Name }}$

Brian K. Culligan

Amy L. Fishburne

Ann Y. Galbraith

Veronica Shaw

Doris L. Simmons

S. Marie Spearman

Pauline D. Tu

Nancy L. Turner

\section{Program Areas}

Clean Water Act, Drain Systems, Unusual Waste Disposal

Air Emissions, Clean Air Act, NESHAPS

Satellite and Staging Area Coordination, Dept. NEPA Coordinator, CERCLA

Radiactive Waste Assay, B-25 Control

Radioactive Waste Management Waste Certification

Land Disposal Regulations, Mixed Waste Waste Tanks

Waste Minimization, EPCRA, Excess Chemicals

TNX Environmental Coordinator, Permitting 


\title{
Environmental Monitoring
}

\author{
Environmental Radiometrics
}

\section{Program Coordinators}

As noted below.

\section{Program Descriptions}

Develop and apply ultra-sensitive analytical systems to environmental systems in anticipation of future compliance issues.

Organizational Responsibility

The Environmental Technology Section (ETS) of SRTC manages this program.

\section{Major Milestones/Accomplishments from FY 93}

- Second-Generation Tritium Effluent Water Monitor - The installation of the TEWM-2 at the -20 foot elevation of the $105-\mathrm{K}$ reactor building was halted due the decision to put the $\mathrm{K}$ - Reactor in a D\&D condition. A second-generation tritium monitor was installed in the process sewer in the $400-\mathrm{D}$ area. (K. J. Hofstetter and R. Eakle)

- Pond C Studies with Underwater HPGe Detector - Analysis of Pond C sediment measurements with the underwater HPGe detector was completed and documented in the report, "Preliminary Summary - Pond C Measurements with Underwater HPGe Detector," SRTC-ETS-93040, Feb 15, 1993. (W. G. Winn)

- $\quad$ EPA Listed Metals in Site Streams and Waters - A study of EPA Listed Metals in Site Streams and Waters was completed and the work reported in SRTC-ETS93258 on July 30,1993 , completing a DOE PEG Milestone. (J. E. Halverson)

- Unmanned Aerial Vehicle (UAV) Data Acquisition System - A collaborative project between Guided Systems Technologies (GST) in Atlanta and ETS has begun to develop a robotic helicopter for performing aerial surveys. This project combines the UAV expertise at GST with the sensor development expertise at SRTC. (K. J. Hofstetter. M. M. Pendergast, \& D. W. Hayes )

- Par Pond Studies with Underwater HPGe Detector - Analysis of PAR Pond Sediments with an underwater HPGe Detector was completed and the results documented in the report, "Measurements of Radionuclides in PAR Pond Sediments with an Underwater HPGe Detector," WSRC-TR-93-209. (W. G. Winn)

- $\quad$ SRS and Vogtle Effluent Studies in Savannah River - The final 1992 summary report of SRS and Vogtle effluent studies in the Savannah River, "Radioactive Effluents in Savannah River - Summary Report for 1992," WSRC-TR-93-473. 
was issued. Concentrations of Cs-137 at Highway 301 Bridge dropped almost an order of magnitude from the nominal $100 \mathrm{fCi} / \mathrm{L}$ observed during the mid-80's. (W. G. Winn)

- Patent Disclosures - Patent disclosures titled, "Mercury Analysis of Aqueous Samples with a Pressurized Probe and DC Discharge Detector," "Portable Mercury Analyzer," and "Inexpensive Method for the Rapid Removal and Recovery of $\mathrm{Hg}$ and other Dissolved Volatile Organic Compounds from Hazardous Aqueous Wastes" were submitted. (E. Villa-Aleman)

\section{Major Milestones for FY 94}

- Ultra Low-Level Analytical Facility - Complete construction of expanded clean room facilities for ultra low-level environmental analyses. Project \#S-4873. (J. E. Halverson)

- Ion Microprobe - Purchase and install an Ion Microprobe for analysis. measurement and characterization of trace levels of isotopes, elements and compounds in environmental samples in support of NESHAP, CERCLA, and Clean Water Act requirements. (D. C. Carison)

Climatology - Site

\section{Program Coordinator}

\section{R. J. Kurzeja}

\section{Program Descriptions}

The purpose of the program is to supply a variety of meteorological data for site support engineering, calculations, compliance and research.

\section{Organizational Responsibility}

The Environmental Technology Section of SRTC manages this program.

\section{Major Milestones/Accomplishments from FY 93}

- Generation of strip charts of all sensor data from 1991- 1993. These charts show data and QA checks of the data.

- Relocation of 2 meter sensors to minimize wind flow obstructions.

- Support data for study on oxygen enrichment in waste tanks.

- Support data for study of tank heating from solar radiation. 


\section{Major Milestones for FY 94}

- Write software to collect and store data at the site. This will permit replacement of data lost during transmission.

- Installation of infrared sensor.

Major Milestones for FY $95-99$

- Installation of bistatic sodar (sound radar) to monitor the lowest 800 meters of the atmosphere.

\section{Meteorological Database Program}

\section{Program Coordinators}

Allen $\mathrm{H}$. Weber

\section{Program Descriptions}

This program updates and compares meteorological data bases collected from the SRS Area and WJBF-TV towers which are archived in the Weather INformation and Display (WIND) System. These data are used in environmental and engineering studies.

\section{Organizational Responsibility}

The Environmental Technology Section of SRTC manages this program.

\section{Major Milestones/Accomplishments from FY 93}

- Produced new 5-year meteorological data base (87-91) for use on site.

- Published "Comparison of Savannah River Site's Meteorological Databases (U)" WSRC-RP-93-269.

\section{Major Milestones for FY 94}

- Provided selected portions of the new data base to help answer questions on environmental impact of new and existing facilities. 


\section{Major Milestones for FY 95-99}

- Produce new 5-year meteorological data base for 92-96.

- Compare new database with 87-91 and 82-86 databases.

Meteorological Monitoring Program

Program Coordinators

Matthew J. Parker

\section{Program Descriptions}

Provide meteorological data for the Weather INformation and Display (WIND) System. These data are used for emergency response support to unplanned atmospheric releases and environmental or engineering studies.

\section{Organizational Responsibility}

The Environmental Technology Section of SRTC manages this program.

\section{Major Milestones/Accomplishments from FY 93}

- Completed an overview description of the entire meteorological monitoring program in "Meteorological Monitoring Program (U)" WSRC-TR-93-0106. Publication is expected in FY94.

- A Comprehensive Compliance Assurance Review (CCAR) of the entire meteorological monitoring program completed by DOE/NUS.

- "Wind Tunnel Study of Meteorological Instrumentation (U)" WSRC-TR-93-359 was completed in the 735-7A wind tunnel facility.

- $\quad$ "Review of the Replacement Facility Tornado Dampers (U)" WSRC-RP-93-50I was completed at the request of the RTF.

\section{Major Milestones for FY 94}

- Complete corrective actions based on CCAR audit.

- Complete scoping studies to improve model 1585 bivane performance.

- Continue to maintain WIND operations in accordance with DOE Orders.

\section{Major Milestones for FY 95.99}

- Refurbish WJBF-TV Tower meteorological monitoring facility. 


\section{Chemical Management, Pollution Prevention, and Other Compliance Programs}

National Environmental Policy Act

Program Coordinator

Ann Y. Galbraith

Program Description

The WSRC NEPA implementation procedure (Environmental Compliance Manual $3 \mathrm{Q}$. procedure 5.1) requires site departments to have Department NEPA coordinators. SRTC has a single Department NEPA coordinator to cover all SRTC departments. The Department Coordinator is responsible for ensuring implementation of NEPA provisions within SRTC. The Department Coordinator screens Environmental Evaluation Checklists to ensure the information is accurate and determine whether further review and analysis is required by the Environmental Protection Department.

\section{Organizational Responsibility}

The Department Coordinator reports to the Environmental Compliance Group of the Laboratory Operations and Services Department.

\section{Major Milestonesfor FY 94}

- Develop a NEPA procedure for SRTC. 


\section{Emergency Planning and Community Right To Know Act}

\section{Program Coordinator}

Pauline D. Tu and Diane K. Singer

Program Descriptions

SARA III reporting is coordinated under this program.

Organizational Responsibility

Personnel in the Laboratory Operations and Services Department consolidate information for SRTC. Chemical coordinators in the various organizations are responsible for keeping chemical inventories and preparing usage data.

Major Milestones/Accomplishments from FY 93

- Submitted SARA III Usage Report for 1992.

- Submitted SRAR III Toxic Chemical Release Report for 1992.

\section{Major Milestones for FY 94}

- Submitted SARA III Usage Report for 1993.

- Submitted SRAR III Toxic Chemical Release Report for 1993.

\section{Major Milestones for FY 95-99}

- $\quad$ Submitted SARA III Usage Reports for 1994-1998.

- Submitted SRAR III Toxic Chemical Release Reports for 1994-1998. 


\section{Natural Resource Protection}

\section{Surface Waters and Wetlands}

\section{Program Coordinators}

Brian K. Culligan and Nancy L. Turner

\section{Program Descriptions}

SRTC releases treated and untreated effluent from Technical Area, TNX \& B-Area facilities. SRTC is custodian of seven NPDES outfalls and several unpermitted outfalls. The NPDES outfalls are sampled monthly for nonradioactive parameters. Two of the outfalls are sampled for radioactive constituents. Storm water permits have been submitted for nine outfalls.

SRTC also owns and operates four permitted wastewater treatment facilities. Two of these facilities release treated effluent through outfalls to site streams and on to the Savannah River. Each process batch is sampled by SRTC personnel and analyzed to ensure compliance with NPDES permit limits.

\section{Organizational Responsibility}

The Laboratory Operations and Services Department is custodian of and operates the outfalls and wastewater treatment facilities. The Environmental Compliance Group provides oversight, guidance and assistance to ensure that SRTC facilities and activities remain in compliance with applicable regulations.

\section{Major Milestones/Accomplishments from FY 93}

- Reduced the ALARA Goal at Outfalls A-001, TNX-I Process Sewer to the site minimum.

- Established $\mathrm{pH}$ discharge criteria for rainwater in dike around 735-A Low Activity tank.

- Completed cost savings estimate on impact on repair of broken trade waste line resulting in dramatic reduction of rainwater infiltration into Low Activity Gallery. It is estimated that an annual savings of $\$ 5$ million dollars will be realized.

- No deficiencies indicated during 3560 Audit.

- No deficiencies indicated during Compliance Sampling Audit.

- Completed Root Cause Analysis on shipment of wastewater to Rollins (New Jersey).

- Submitted NPDES permit renewals for outfalls A-001, B-005 and no discharge permit for outfall A-025. 
- Developed plan and obtained approval from SCDHEC to use mercury removal and filtration system (MRFS). Test run on first batch of wastewater reduced $\mathrm{Hg}$ concentration from $1581 \mathrm{ppb}$ to $21 \mathrm{ppb}$.

\section{Major Milestones for FY 94}

- Update BMP and SPCC annually / Biannually as required.

- Negotiate new NPDES permit conditions and ensure compliance when issued by SCDHEC.

- Complete mercury decontamination at the 607-17A Waste Neutralization Facility and retum to routine operation of the facility.

- Revise wastewater permit for the 607-17A facility.

\section{Major Milestones for FY 95-99}

- Submit waste water permit modification for $607-17 \mathrm{~A}$.

- Update BMP/SPCC annually or biannually.

- Conduct Toxicity Identification Evaluation.

- Investigate combining area outfalls in 700 Area. 


\title{
Waste Management and Disposal
}

\author{
Waste Management
}

\section{Program Coordinators}

Doris L. Simmons, Ann Y. Galbraith, S. Marie Spearman. Nancy L. Turner

\section{Program Description}

SRTC generates sanitary, low level, TRU, WIPP, hazardous and mixed waste. SRTC waste handling facilities include numerous hazardous waste satellite areas, hazardous waste 90-day staging areas, a waste assay facility, a low level waste storage yard. and a RCRA Treatment, Storage and Disposal (TSD) facility.

\section{Organizational Responsibility}

The TNX Operations Section operates the TNX staging area. The Laboratory Services Section operates the waste assay facility, low-level waste storage yard and the RCRA TSD. Organizations generating hazardous and mixed waste are custodians of the satellite areas and the remaining staging areas. The Environmental Compliance Group (ECG) provides guidance, assistance and oversight to ensure compliance with applicable regulations. The ECG also is responsible for coordinating the waste minimization program.

\section{Major Milestones/Accomplishments from FY 93}

- Completed visual inspections of the high and low activity waste storage tanks' (TSD facility) secondary containment and repairs of minor cracking.

- Completed conducting nondestructive integrity tests on the high and low activity waste storage tanks.

- Began upgrade and replacement of 776-5A HEPA filter housing in preparation for decontamination and coating of high and low activity waste storage tanks' (TSD facility) secondary containment.

- No major findings from the SCDHEC CME audit.

- Began developing waste certification program for SRTC low level and mixed waste.

- Conducted self assessment on TRU waste.

- Conducted process waste assessment for hazardous wastes.

- Submitted Quarterly Hazardous Waste Reports. 
Major Milestones for FY 94

- Complete replacement of 776-5A HEPA filter housing in preparation for decontamination of high and low activity waste storage tanks' (TSD facility) secondary containment.

- Begin decontamination of high and low activity waste storage tanks' secondary containment.

- Complete development of waste certification program for SRTC low level and mixed waste.

- Complete process waste assessment for hazardous wastes.

- Purchase new waste assay equipment.

\section{Major Milestones for FY 95-99}

- Develop and implement waste certification programs for other waste categories.

- Begin project to replace low activity drain system at Building 735-A (target project authorization date - 1999).

Waste Minimization

Program Coordinators

Pauline D. Tu and Diane K. Singer

\section{Program Description}

SRTC's waste minimization plan is documented in the Savannah River Laboratory Procedures Manual, Ll, procedure 6.12. The plan is approved by the SRTC Vice President to demonstrate SRTC's commitment to WSRC's goal of waste minimization. The program covers all types of wastes generated by current and future activities. The focus of the program is on waste reduction by source reduction, recycling and treatment. Program elements include waste inventories and characterization. developing baseline criteria, conducting research and development, conducting process waste assessments, and setting goals and milestones.

\section{Organizational Responsibility}

The Environmental Compliance Group of Laboratory Operations and Services is responsible for developing, managing, tracking and updating the waste minimization plan. All people using SRTC facilities are responsible for implementing the plan. The SRTC research organizations are responsible for conducting research and development in waste minimization techniques. 


\section{Major Milestones/Accomplishments from FY 93}

- Revised SRTC waste minimization plan.

- Conducted Process Waste Assessment on hazardous waste.

- Reduced generation of "routine waste" B-25 boxes by $20 \%$

\section{Major Milestones for FY 94}

- Revise SRTC waste minimization plan.

- Complete Process Waste Assessment on hazardous waste

- Reduce generation of "routine waste" B-25 boxes by $5 \%$

\section{Major Milestones for FY 95.99}

- Revise SRTC waste minimization plan annually.

- Conduct Process Waste Assessments on other waste categories. 


\title{
Atmospheric Protection Program
}

Ozone Depleting Substances (ODS) Compliance Program

\author{
Program Coordinators
}

Amy L. Fishburne and Nancy L. Turner

\section{Program Description}

The Ozone Depleting Substances (ODS) program was initiated by the new regulaticn 40 CFR 82 promulgated under Title VI of the Clean Air Act Amendments. This rule regulates the venting, reusing, handling, leaking, disposal, record keepinng, and phase out of Class I and II ODSs. SRTC has begun activities to meet the requirements of this new program.

\section{Organizational Responsibility}

The Environmental Compliance Group is coordinating this effort with other groups in the Laboratory Operations and Services Department.

\section{Major Milestones/Accomplishments from FY 93}

- Established a record keeping logbook for equipment which uses more than 50 pounds of refrigerant in order to track maintenance and leak rates.

\section{Major Milestones for FY 95-99}

- Complete training and certification of refrigerant technicians by regulatory deadline $(11 / 14 / 94)$. 
Air Permitting Program

Program Coordinators

Amy L. Fishburne and Nancy L. Turner

\section{Program Description}

The current air permitting program is based on the Clean Air Act (CAA) prior to the 1990 Amendments and regulates only a handful of air pollutants. The permitted sources at SRTC are the Plutonium Waste Incinerator, Off-gas Component Test Facility, Precipitate Hydrolosis Experimental Facility, and eight diesel generators. A new SCDHEC air permitting program will be instituted once approved by EPA. SCDHEC will permit sources emitting above certain levels of over 27 air toxics. This new permitting program will be in accordance with Title $V$ of the new CAA and will fall under the Air Toxics Program at SRTC.

\section{Organizational Responsibility}

The Environmental Compliance Group is coordinating this effort with other groups in the Laboratory Operations and Services Department.

\section{Major Milestones/Accomplishments from FY 93}

- Assumed custodianship of three additional permitted diesel generators in the Technical Area.

- Incurred no findings or areas of concern in the SCDHEC Annual Inspection of SRS permitted sources.

\section{Major Milestones for FY 94}

- Complete required information for the new SRS Air Permit. 
Air Toxics Program

Program Coordinators

Amy L. Fishburne and Nancy L. Turner

\section{Program Description}

The air toxics program covers compoliance with regulations pertaining to air pollutants other than radionuclides. This includes a list of 189 Hazardous Aır Pollutants (HAPs) designated in the SCDHEC Standard 8 Regulations. A new SCDHEC air permitting program will be instituted once approved by EPA. SCDHEC will permit sources emitting above certain levels of these pollutants. The require:- $\cdot 7 t$ to perform the annual Air Emissions Inventory (AEI) comes from the Standa 3 regulation.

\section{Organizational Responsibility}

The Environmental Compliance Group is coordinating this effort with other groups in the Laboratory Operations and Services Department.

\section{Major Milestones/Accomplishments from FY 93}

- Completed the baseline AEI for all SRTC facilities for the years 1985 - 1991 .

\section{Major Milestones for FY 94}

- Complete the SRTC 1992/1993 AEI.

\section{Major Milestones for FY 95-99}

- Complete the annual AEI for SRTC. 


\section{Radionuclide NESHAPS Program}

\section{Program Coordinators}

Amy L. Fishburne

Program Description

The radionuclide NESHAP program is based on meeting the requirements of 40 CFR 61. SRTC has approximately 20 radiological emission points, five of which are monitored. Much of the effort spent in this program in 1992 and 1993 was in negotiating an amendment to the SRS NESHAP Federal Facility Compliance Agreement (FFCA) to include upgrading SRTC stacks, assisting in designing sampling systems, and meeting FFCA milestones.

\section{Organizational Responsibility}

Laboratory Operations and Services is custodian of the faciliies and coordinates involvement with other groups, such as the Environmental Protection Department and RCO.

\section{Major Milestones/Accomplishments from FY 93}

- Successfully negotiated an amendment to the SRS NESHAP FFCA to upgrade three SRTC stacks. All 1993 SRTC FFCA commitments were met on time or ahead of schedule. Elimination of one other stack from the upgrade commitment saved $\$ 750,000$.

- Installed a new sampler in the 735-A stack.

- Designed, fabricated, and tested the Gauldin sampler which will become the site standard for unmonitored perticulate sampling. The team received division and site Total Quality Awards and a bronze George Westinghouse Signature Award.

- Obtained EPA approval to use the tracer gas flow meter method and to place the sample boxes at ground level, saving $\$ 362,000$.

\section{Major Milestones for FY 94}

- Install new HEPA filter housing unit at 776-5A.

- Install Gauldin sampler, new monitor, and sample line splitter at 776-5A.

- Meet FY 94 FFCA commitments and beging operating sampling systems by the end of the fiscal year.

- Install Gauldin sampler at 735-A.

\section{Major Milestones for FY 95-99}

- Certify compliance of the upgraded sampling systems and submit information to EPA. 


\title{
Non Radioactive Air Emissions Regulatory Modeling
}

\author{
Program Coordinators
}

John Stewart and Chuck Hunter

\section{Program Description}

Support the SRS EPD by providing regulatory air quality modeling. Model atmospheric emissions from new sources and modified existing sources for operating permits; determine site compliance with the federal and state ambient air quality standards by dispersion modeling of pollutant concentrations at the site boundary and beyond as necessary. Maintain IBM PC-compatible site emissions databases for use in regulatory and related air quality modeling.

\section{Organizational Responsibility}

The Environmental Technology Sectiom of SRTC is responsible for this program.

\section{Major Milestones/Accomplishments from FY 93}

- Demonstrate site compliance with the South Carolina ambient air quality standards regulating emissions of 85 toxic air pollutants, June, 1993.

- Model the maximum potential site boundary concentrations of 139 air toxics and 7 criteria pollutants to provide information SRS was required to give to the State of South Carolina under the State Implementation Plan approved by the EPA to implement the Clean Air Act and the Clean Air Act Amendments (CAAA), September, 1993.

- Support Design Engineering and other groups by supplying modeling output for inclusion in air permit applications.

\section{Major Milestones for FY 94}

- Complete the SRS air quality modeling contribution to the Spent Nuclear Fuel Environmental Impact Statement being prepared for the DOE complex.

- Complete quality assurance of the ETS/ETG air quality modeling databases.

- Conduct systematic site modeling of pollutants regulated under OSHA standards.

- Continue to support the EPD in obtaining source and site operating permits under the provisions of the CAAA.

Major Milestones for FY 95-99

- Continue to support the EPD with regulatory air quality modeling to enable it to meet deadlines associated with the implementation of more complex provisions of the CAAA. 


\title{
AIR Emissions ALARA
}

\section{Program Coordinators}

\author{
A. L. Fishburne
}

\section{Program Description}

The air emissions ALARA (As Low As Reasonably Achievable) was developed to set goals to try to reduce radiological emissions as low as reasonably achievable. The ALARA Guides Committee establishes these goals and trends data received in the monthly radiological release report generated by EMS. EMS is responsible for analyzing air and liquid samples.

\section{Organizational Responsibility}

LAbopratory Operations and Services provides input for the ALARA Guides Committee to establish these goals. EMS is responsible for analyzing air samples.

\section{Major Milestones/Accomplishments from FY 93}

- Developed SRTC Airborne Release Prevention and Control Plan. Completed 11 of 16 SRTC action items.

- Created SRTC Air Team, comprised of personnel from engineering. environmental, and ALARA groups, plus Health Protection. This team meets on an as neede basis to facilitate communications and resolve interdisciplinary issues related to Air emissions.

- Established ALARA goals, tracked and trended emissions.

\section{Major Milestones for FY 94}

- Complete remaining action items from the Airborne Release Prevention and Control Plan. 


\title{
Environmental Restoration
}

\author{
Environmental Restoration
}

Program Coordinator

Nancy L. Turner and Ann Y. Galbraith

\section{Program Description}

Environmental Restoration (ER) has one closure project in process at the TNX facility and one adjacent to the Technical Area. The closure plan for the New - VX Seepage Basin and the work plan for the 904-A trench waste site are currently in SCDHEC for review. Future ER projects include further characterization and review of the Old TNX Burying Ground and the Old TNX Seepage Basin.

Environmental Sciences Section (ESS) has several current and projected remediation projects for the TNX facility. Currently, TOS personnel are operating a trickle flow bioreactor to treat groundwater contaminated with volatiles. They are also supporting an in situ bioremediation project concerning the 678-T diesel spill. Future ESS projects include two additional bioreactor units.

The trickle flow bioreactor discharges to the TNX Organic Removal Facility to Outfall $\mathrm{X}-014$ and on to the Savannah River via Outfall X-008.

\section{Organizational Responsibility}

ER is responsible for ensuring that all closure projects are in compliance with applicable federal and state regulations. The Environmental Compliance Group (ECG) of SRTC is responsible for oversight and support of the ESS groundwater remediation program at TNX. Document preparation associated with the 904-A trench waste site is being managed by the ECG rather than ER because the site is still an active facility. The ECG will also provide project liaison between operations groups, $E R$, and ESS on all future remediation efforts in SRTC facilities.

\section{Major Milestones/Accomplishments from FY 93}

- Obtained a SCDHEC industrial wastewater operating permit for the trickle flow bioreactor.

- Coordinated permitting requirements for the mobile bioreactor unit. 


\section{Major Milestones for FY 94}

- Continue work on the 904-A trench waste site according to approved schedules.

- Coordinate permitting requirements for the Fluidized Expanded Bed Bioreactor Unit and the gas phase bioreactor.

- Begin electrokinetic migration study at the Old TNX Seepage Basin. 


\title{
Emergency Response, Environmental Occurrence Reporting, and Regulatory Notification
}

\author{
Technology Support for Emergency Response
}

\author{
Program Coordinator \\ C. H. Hunter
}

\section{Program Description}

Continue development, operation, and maintenance of the Weather INformation and Display (WIND) System and the Tracking Radioactive Atmospheric Contaminants (TRAC) Vehicle as state-of- the-science resources for assessing the environmental consequlences of hazardous material releases to the environment.

\section{Organizational Responsibility}

This program is managed by the Eviromental Techology Section of SRTC.

\section{Major Milestones/Accomplishments from FY 93}

- WIND System computer resources were available $99.3 \%$ of the time sitewide and more than $99.9 \%$ of the time in the SRS Operations Center.

- Upgrades to the WIND System's Puff/Plume atmospheric transport/dosim code were implemented. These upgrades provided significant improvement ! ability to assess environmental consequences of chemical releases close $t$ source of the spill.

- A prototype version of an advanced WIND System workstation was develope The advanced workstation provides operation in a 'windowed' environment and features high-resolution color graphics, time sequenced animation, and incorporation of Geographic Information System (GIS) map overlays.

- Completed major upgrade to the TRAC Vehicle onboard computer system for data acquisition.

\section{Major Milestones for FY 94}

- Operational implementation of the WIND System workstation capabilities in the Consolidated Emergency Response Facilities.

- Development and implementation of a WIND System computer code to model hazardous chemical releases for emergency response.

Major Milestones for FY $95-99$ 
- Continued development of the advanced WIND System workstation.

- Complete upgrade of nuclear counting systems on TRAC.

- Implementation of an advanced 3-dimensional wind field model for SRS and the surrounding region. This model is expected to provide much more realistic realtime simulation of the atmospheric transport of hazardous material. 


\title{
Site Services Division Environmental Summary
}

\author{
Department
}

Analytical Laboratories Department

\section{Mission}

The mission of Analytical Laboratories is to provide quality analytical services in support of site operations to allow Savannah River Site to comply with legal, regulatory, contractual, and corporate requirements.

Vision

The Analytical Laboratories vision is to be the recognized model of excellence for laboratories providing analytical services within the Department of Energy Complex and the Westinghouse Electric Corporation.

\section{Lead Environmental Coordinator}

Mark Kidd

\section{Environmental Challenges \& Issues from Projected Mission Changes during Next Five Years}

Some of the environmental challenges identified for Analytical Laboratories Department include the following:

- Changes in requirements from regulating agencies will impact the amount of documentation required for the data packages from the laboratory, as well as increasing quality assurance and review of the data packages. In addition, an increase in certified analyses is anticipated.

- Need to provide analytical support to site organizations' implementation of the waste acceptance criteria.

- Expand radiometric and chemical analyses for high alpha and beta gamma waste and materials.

- Increase analytical capability supporting environmental permitting compliance. 


\section{Atmospheric Protection}

\section{Air Emissions}

Program Coordinator

Mark Kidd

\section{Program Description}

Taking appropriate measures to ensure that new and existing facilities comply witi current regulatory requirements.

\section{Organizational Responsibility}

Analytical Laboratories Department is responsible for the operation of 772-D, $772-\mathrm{F} / \mathrm{lF} / 4 \mathrm{~F}$ laboratory facilities.

\section{Major Milestones Accomplished in FY 92}

- Completed Air emission inventories for 772-D facility. Central Laboratories (772-F and 772-1F) currently conducting air emissions inventory.

- $772-4 \mathrm{~F}$ is being constructed under the October 1991 Federal Facilities Compliance Agreement for Radionuclide NESHAP. The $772-4 \mathrm{~F}$ stack is an environmental and safety upgrade and will enable $772-F$ laboratory facility to return from current limited operation to full operation.

\section{Major Milestones Accomplished in FY 93}

- Hot tie-in and continuous operation of the 772-4F stack.

- Participated with the Environmental Release Guides Committee and the ALARA Management Steering Committee to look at potential accidental airborne radioactive releases and means for minimizing risk or impact for $772-\mathrm{F}$ and $772-1 F$ laboratory facilities. Committees developed an Airborne Release Prevention and Control Plan.

\section{Major Milestones for FY 94-98}

Restart of 772-F laboratory- Projected for December 1996. 


\section{Site Services Division Environmental Summary}

Department

Central Services Works Engineering (CSWE)

Mission

CSWE pledges to provide quality works engineering services and training in a way that meets our customers' needs while having no injuries, operating within budget constraints, and maintaining high morale so that process downtime is minimized, the environment is maintained or improved, and site commitments to DOE are satisfied.

\section{Vision}

To be recognized by our internal customers as the best maintenance organization at SRS and to be recognized by DOE as the best in the DOE complex.

\section{Lead Environmental Coordinator}

Traci A. Richardson

\section{Environmental Accomplishments}

Established Sitewide Petroleum Contaminated Soil (PCS) Storage and Bioremediation Program.

Worked with EPD and Bechtel to develop Sitewide Fluorescent Light Tube Crushing Program for disposal of used tubes.

Developed 11 Departmental Level Procedures for inclusion in 3Q6 Manual 


\section{Environmental Challenges and Issues from Projected Mission Changes During the Next Five Years}

A significant amount of Site maintenance items are projected to be subcontracted to offsite within the next five years. If this occurs, CSWE's mission will be to oversee these subcontracts. The following challenges and issues are identified:

* Develop programs for ensuring environmental compliance by all subcontractors.

* Impress upon subcontractors the importance of environmental compliance.

* Develop environmental training programs for subcontractors.

* Train STRs (Subcontract Technical Representatives) to develop specific Scopes of Work relative to environmental issues (i.e. Identify waste streams and methods of waste disposal before generation, identify areas of waste minimization by subcontractors, etc) 


\section{Chemical Management, Pollution Prevention, and Other Compliance Programs}

Pesticide Program

Program Coordinator

T.A. Richardson

Field Coordinator

T. McCormick

\section{Program Description}

CSWE has a 2 man crew (located in Central Shops) to apply approved pesticides to bare ground applications (i.e. parking lots, RCAs, IDA zones, and gravel laydown yards). In general, two subcontractors (Railroad Ballast Subcontractor and Utility Right-of-Way Subcontractor) assist the CSWE crew in the application process. Most pesticides are applied between the months of March-October. Excess pesticide material is stored in Building 709-N.

Organizational Responsibility

CSWE is responsible for vegetation control involving bare ground applications. CSWE maintains STR (Subcontract Technical Representative) responsibilities for two pesticide contracts (railroad and utility right-of-ways) as well as two certified applicators within the department. Fire ant control is also available through this program.

\section{Major Milestones Accomplished in FY93}

Maintained vegetative control for 450 acres with 2 man crew \& met customer's needs.

Completed 3 Site Use packages for 1994 pesticide work.

Nominated for George Westinghouse Signature Award

Major Milestones for FY94

Continue implementation of program. 


\title{
Natural Resource Protection, Land Use \& Wildlife
}

\section{Petroleum Contaminated Soil Storage (PCS) and Bioremediation Facility}

\author{
Program Coordinator
}

T.A. Richardson

Field Coordinator

J. Kirby; M. Waltz

\section{Program Description}

In FY'94, CSWE will store all non-hazardous and non-radioactive PCS material for SRS at the Central PCS Storage Facility (CPCSSF) located in D-area. CSWE will also operate the Bioremediation Facility which will serve to prepare the PCS for use as landfill cover or backfill material. The FY' 94 customer cost for PCS storage and bioremediation is $\$ 41.00$ per cubic yard per month (NOTE: A minimum of 2 months is required for the bioremediation process).

\section{Organizational Responsibility}

CSWE will serve as custodian of both the Central PCS Storage Facility and the Bioremediation Facility. CSWE is responsible for complying with the 3Q ECM 6.23 Waste Acceptance Criteria procedure for these facilities. CSWE will also store the PCS in accordance with applicable SCDHEC requirements and operate the Bioremediation Facility according to its permit (with technical assistance from SRTC). The waste generator must properly characterize the PCS and adhere to the Waste Acceptance Criteria for storage of PCS.

\section{Major Milestones Accomplished in FY93}

The PCS Task Team developed the 3Q ECM 6.23 Waste Acceptance Criteria procedure which identifies the required analysis and steps needed to store PCS at the CPCSSF.

Construction of the Central PCS Storage Facility $\left(500^{\prime} \mathrm{X} 400^{\prime}\right)$ was completed in September 1993

Construction of the Bioremediation Facility $\left(400^{\prime} \mathrm{X} 40^{\prime}\right)$ was completed in October 1993 
Major Milestones for FY94

Operate CPCSSF and Bioremediation Facility in compliance with 3Q ECM 6.23 and permit conditions.

Assist SRTC in development of sampling protocol for Bioremediation Facility (as necessary).

Creosote Wood Storage

Program Coordinator

T.A. Richardson

Field Coordinator

J. Grimes

\section{Program Description}

CSWE stores used creosote fence posts, guard rail posts, railroad ties, and powerpoles at Gunsite 12 per 3Q6 3-60008. A small number of these products are free-released by HP for sale off-site. The majority of this wood, however, is stored for future use onsite at SRS (i.e. erosion control, construction projects, etc). Individuals interested in this material must contact CSWE.

\section{Organizational Responsibility}

CSWE is custodian of the Gunsite 12 Creosote Wood Storage Area. As custodian, CSWE is responsible for controlling access to Gunsite 12 and approving material to be stored at Gunsite 12. The wood generator is responsible for completing the Creosote Wood Data Sheet, obtaining HP surveys (as needed), contacting CSWE prior to wood delivery, and following the applicable CSWE procedure (3Q6 3-60008).

Major Milestones Accomplished in FY93

NONE

Major Milestones for FY94-96

Work with Site Services Engineering (SSE) and Power to chip the creosote wood and use as a fuel additive in the D-area Powerhouse. 


\title{
Natural Resource Protection, Surface Water \& Wetlands
}

NPDES Outfalls

\author{
Program Coordinator
}

T.A. Richardson

Field Custodians

P.F. Beck (A005); E. McCalister (CSO14); R.M. Eberl (CYO01)

\section{Program Description}

CSWE is custodian of 3 NPDES outfalls. The CS-014 and CY-001 outfalls receive stormwater runoff only. The A005 outfall receives stormwater from upper 700-area as well as discharge from the SREL duck ponds.

\section{Organizational Responsibility}

CSWE is responsible for maintaining compliance at each outfall and operating within permit limits. Each department that discharges into one of the CSWE outfalls is also responsible for operating within permit limits so as not to put the outfall out of compliance.

\section{Major Milestones Accomplished in FY93}

Operated all NPDES outfalls within permit limits.

Obtained approval from SCDHEC to move fecal coliform sampling point. Instead of sampling approximately 5 feet downstream of discharge, the sampling point is now located at the end of the discharge pipe. This alleviates the problems encountered with ducks swimming around the "old" sample point and distorting the fecal coliform levels.

\section{Major Milestones for FY94}

Maintain compliance and operate within permit limits. 


\section{Groundwater Protection}

Removal of USTs

Program Coordinator

T.A. Richardson

Field Coordinator

J. Lonon

\section{Program Description}

CSWE removes abandoned Underground Storage Tanks (USTs) across the site. Services rendered include pumping product from the tank, properly venting the tank. excavating the tank, and backfilling. CSWE will provide assistance with soil sampling and tank disposal as needed.

\section{Organizational Responsibility}

CSWE is responsible for providing the equipment and personnel necessary for removing the USTs. The tank owner is responsible for notifying EPD prior to tank removal, submitting a work order to CSWE, disposing of any liquid removed. obtaining necessary soil samples, submitting closure reports to EPD, and disposing of the tank.

\section{Major Milestones Accomplished in FY93}

Crushed 22 tanks (CSWE's Power's, Reactor's) and sent to SRS Scrap Metal vendor for use as scrap metal..

\section{Major Milestones for FY94}

Remove USTs at B-area and Excess Facility. 


\section{Waste Management \& Disposal}

\section{Oil Filter Compacting}

\section{Program Coordinator}

T.A. Richardson

\section{Field Coordinator}

R.M. Eberl

\section{Program Description}

CSWE's Railroad and Light Equipment Shop drains oil from the oil filters removed during maintenance of the site's light equipment and locomotive fleet. Once the filters are drained, they are compacted to $1 / 3$ its original size. This program removes $80 \%$ more oil from the filter as opposed to gravity draining only.

\section{Organizational Responsibility}

CSWE is responsible for servicing the WSRC light equipment and locomotive fleet. Compaction of oil filters removed during this servicing activity is the responsibility of CSWE's Railroad and Light Equipment Shop.

\section{Major Milestones Accomplished in FY93}

Compacted over 2,000 oil filters which saved 33 cubic feet of landfill space AND prevented approximately 700 gallons of oil from reaching the landfill through solid waste disposal. This was approximately $75 \%$ of the filters compacted in FY' 92 due to GSA takeover of vehicle maintenance.

Purchased drum heater which allows mechanics to remove cold oil filters (safety reasons) and heat the filter up to engine operating temperature at a later time to remove the oil.

\section{Major Milestones for FY94}

None identified to date. 


\section{Used Machine Coolant Recycling}

\section{Program Coordinator}

T.A. Richardson

Field Coordinator

M.P. Flanders

\section{Program Description}

CSWE"s 717-A Machine Shop has procured a unit that will recycle 100 gallons of used machine coolant per day. The recycled product has been tested in various machines and has performed well.

\section{Organizational Responsibility}

CSWE provides machine coolant recycling service to all WSRC organizations. The owner of the used coolant shall provide CSWE with a Work Request, blue tag, and an empty drum (to be used for the recycled product). CSWE will recycle the coolant. place it into the new drum, band the material for shipment, and contact the owner within 2 weeks for pick up.

\section{Major Milestones Accomplished in FY93}

Recycled approximately 600 gallons of used machine coolant.

\section{Major Milestones for FY94}

- Continue recycling for the site. 


\section{Scrap Metal Shavings Recycling Program}

\section{Program Coordinator}

T.A. Richardson

\section{Field Coordinator}

M.P. Flanders

\section{Program Description}

CSWE's 717-A Machine Shop has developed a program for segregating scrap metal shavings (i.e. aluminum, carbon steel, stainless steel, copper) throughout the shop, placing them into separate storage bins, and sending to Salvage for sale to the SRS Scrap Metal Vendor. CSWE can provide program details to any shop wishing to implement the same program in their area.

\section{Organizational Responsibility}

CSWE is responsible for minimizing waste sent to the Sanitary landfill - the Scrap Metal Shavings Recycling Program helps to avoid the disposal of 25 dumpsters of scrap metal shavings per year.

\section{Major Milestones Accomplished in FY93}

Developed program, wrote implementation procedure, and obtained storage bins.

\section{Major Milestones for FY94}

None identified to date. 
Fluorescent Bulb Crushing

\section{Program Coordinator}

T.A. Richardson

Field Coordinator

H.J. Snellings

\section{Program Description}

CSWE provides selected site areas (700-area, M-area, D-area, SRTC, SREL, SRFS) with the service of fluorescent tube crushing for non-RCA bulbs only. This process is required to reduce the size of all used fluorescent tubes prior to shipping to Waste Management for disposal. The CSWE Tube Crusher is located in $722-7 \mathrm{~A}$ and is operated daily from $8: 30 \mathrm{am}-4: 00 \mathrm{pm}$.

\section{Organizational Responsibility}

CSWE is responsible for storing all fluorescent tubes (from selected areas noted above) in the $722-7 \mathrm{~A}$ Staging Area, crushing the tubes, and shipping to Waste Management within 90 calendar days from the date they were first received into the 722-7A Staging Area. Generators of used tubes are responsible for following CSWE Environmental Procedure 3Q6 3-60015 and providing a Work Request and blue tag (with exact number of bulbs) with each shipment of bulbs.

\section{Major Milestones Accomplished in FY93}

Developed program, wrote 3Q6 3-60015 procedure, established 722-7A Staging Area. and procured tube crusher.

\section{Major Milestones for FY94}

Continue implementation of program. 


\title{
Site Services Division Environmental Summary
}

\section{Department}

Site Services Engineering (SSE)

Mission

To provide engineering design and technical support to our customers in a way that is value-added, environmentally responsible, and protects the health and safety of all employees.

Vision

To be recognized as the value-added leader in technical and engineering excellence in support of our customers' facilities and processes.

\section{Lead Environmental Coordinator}

\author{
Allen B. Edenfield
}

\section{Environmental Planning}

The following documents contain environmental information about SSE programs:

Savannah River Site FY94 Operating Plan

Environmental Implementation Plan, WSRC-IM-93-17

SSE Environmental \& Chemical Systems Group FY94 Strategic Plan

Site'Services Division FY93 Annual Self-Assessment of Operations 


\section{Chemical Management, Pollution Prevention, and other Compliance Programs}

Domestic Water Systems

Program Coordinator

Robert D. Turner

Program Description

Verify site domestic water supplies meet all SCDHEC water quality standards. Meet SCDHEC commitments for implementing the sitewide cross connection control program. Comply with the SCDHEC lead and copper rule. Meet SCDHEC commitments for scheduled completion of domestic water upgrade projects. Provide technical support to the operation of the site well complex, including the formal closure of inactive production wells per SCDHEC requirements.

\section{Major Milestones Accomplished in FY93}

- Completed baseline and first round compliance sampling of all site domestic water systems for lead and copper.

- Completed engineering study for consolidating sitewide domestic water systems and obtained SCDHEC concurrence.

- Started up new domestic water systems in D- and K-Areas.

- Analyzed all site domestic water supplies for SCDHEC regulated contaminants.

- Completed cross connection inspection for $70 \%$ of total site facilities.

\section{Major Milestones for FY94}

- Analyze all site domestic water supplies for SCDHEC regulated contaminants.

- Complete cross connection inspection for all site facilities.

- Complete compliance sampling of all site domestic water systems for lead and copper.

- Implement corrective action plan for lead and copper in Forestry water system.

- Abandon six inactive production wells.

Major Milestones for FY95-99

- Analyze all site domestic water supplies for SCDHEC regulated contaminants.

- Complete and start up consolidated domestic water systems.

- Abandon inactive production wells.

- Ongoing sampling/analysis of the all domestic water supplies for lead and copper. 


\section{Natural Resource Protection, Surface Water \& Wetlands}

Waste Treatment Facilities

Program Coordinator

Ronda L. Huffines

\section{Program Description}

Provide an environmentally beneficial method of disposing sludge from all site sanitary wastewater treatment plants(SWTPs). Provide guidance to the expansion/consolidation of SWTPs. Provide technical guidance to the operation of SWTPs in efficient and environmentally sound manner.

Major Milestones Accomplished in FY93

- Submitted Central Sanitary Wastewater Treatment Facility (CSWTF) Engineering Report to SCDHEC for approval.

- Completed Title II Design for CSWTF collection system.

- Obtained FONSI on EA for centralization.

\section{Major Milestones for FY94}

- Obtain SCDHEC permit for sludge application to forested areas.

- Obtain FONSI on EA for sludge land application.

- Obtain NPDES permit for CSWTF outfall.

- Obtain SCDHEC approval of Preliminary Engineering Report for SWTP centralization.

- Start construction on 1.05 MGD centralized SWTP and collection system.

Major Milestones for FY95-99

- Complete centralization project construction and place new facilities in service.

- Eliminate all chlorine discharges through use of ultraviolet light disinfection.

- Obtain SCDHEC certification for NPDES parameters at the CSWTF process control station. 


\section{Natural Resource Protection, Surface Water \& Wetlands}

\section{NPDES}

\section{Program Coordinator}

Brian D. Silas

\section{Program Description}

Coordinate Site Services Division(SSD) preparation and follow-up for the 3560 aud.t Provide technical support for compliance with the NPDES permit. Participate on Site Toxic Control Strategy Team.

\section{Major Milestones Accomplished in FY93}

- Supported 3560 audit--all SSD outfalls in compliance.

- Completed testing of SSD outfalls in support of the completion of the NPDES 2-C applications for SCDHEC.

\section{Major Milestones for FY94}

- Support 3560 audit.

- Provide technical support for the negotiation of the new NPDES permit.

- Develop plan to combine NPDES outfalls which have duplicate monitoring requirements.

- Recommend actions needed to eliminate toxicity at SSD outfalls.

\section{Major Milestones for FY95-99}

- Support NPDES permit negotiations.

- Support projects to eliminate toxicity at SSD outfalls. 


\section{Atmospheric Protection}

\section{Air Emissions}

\section{Program Coordinator}

Kevin R. Scaggs

\section{Program Description}

Provide technical support to Power Operations for meeting boiler emission compliance testing. Provide NESHAP stack airflow measurements for site's radionuclide emission points. Update EPD on changes to Site Utilities facilities which may affect the air emissions inventory.

\section{Major Milestones Accomplished in FY93}

- Compliance tested boilers A-1, A-2, D-2, D-4, H-1, and H-2.

- Conducted NESHAP stack measurements for all areas.

- Updated air emissions inventory data for SUD.

- Incorporated HEPA filter testing group into SSE.

- Participated in indoor air quality investigations with Indusurial Hygiene.

\section{Major Milestones for FY94}

- Compliance testing of boilers D-1, D-3, and H-3.

- Monitor SUD facilities for changes affecting air emissions inventory.

- Conduct NESHAP stack measurements for all areas.

- Renew air permits for SUD boilers and diesel generators.

- Submit air permit application for burning used railroad crossties in Di-Area boilers.

\section{Major Milestones for FY95-99}

- Obtain new contract for boiler compliance testing.

- Update air emissions inventory.

- Participate in Clean Air Act Title V air permitting effort.

- Continue NESHAP stack measurement service for all areas. 


\section{Waste Management \& Disposal}

Waste Management

\section{Program Coordinator}

James H. Riggsbee

\section{Program Description}

Provide technical assistance to SSD for the management of RCRA hazardous was:t. Provide technical support to Power Operations for the closure of underground storage tanks. Support SSD preparation and follow-up for the annual CME audit. Provide technical leadership to SSD departments required to prepare waste minimization plans per DOE Order 5400.1.

\section{Major Milestones Accomplished in FY93}

- Developed and presented RCRA training to SSD personnel responsible for inspecting acid/caustic basins.

- Supported SSD departments in preparation and follow-up to CME audit.

- Prepared and submitted on schedule all hazardous waste quarterly reports.

\section{Major Milestones for FY94}

- Provide assistance in Power Operations development of a corrective action plan for closure of 108-3P underground storage tank site.

- Provide technical support for CME audit.

- Support SSD departments preparing CY94 waste minimization plans.

\section{Major Milestones for FY95-99}

- Support SSD departments in revision of waste minimization plans.

- Provide technical support for CME audits. 


\title{
Site Services Division Environmental Summary
}

\section{Department}

Site Services Training (SST)

\author{
Mission
}

To provide training support to Environmental Coordinators of SSD in a way that is value-added, environmentally responsible, and protects the health and safety of all employees.

Vision

To be recognized as the value-added leader in training excellence within WSRC and the DOE complex.

\section{Lead Environmental Coordinator}

Roy Davenport / Keith Anderson 


\section{Environmental Coordinator Training Matrix}

Training Requirements

Program Coordinator

Roy Davenport / Keith Anderson. Phil Mottel, Allen Edenfield

\section{Program Description}

Site Services Training and the SSD Environmental Council have developed a matrix of initial training requirements for each SSD Environmental Coordinator. The requirements are recorded in IOM SSD-ADM-930794.

\section{Major Milestones Accomplished in FY93}

- Initiated "proactive" effort to develop initial training requirements for Department Environmental Coordinators

- Obtained approval for the training matrix from affected organizations \& the SSD Environmental Council Chairman

- Issued training matrix to SSD Environmental Coordinators

\section{Major Milestones for FY94}

- Document training progress for SSD Environmental Coordinators

- Revise / Update training matrix requirements as 'sessary to satisfy emerging training needs

Major Milestones for FY95-99

- none 


\section{RCRA Satellite Area Operation}

RCRA

Program Coordinator

Roy Davenport / Keith Anderson. Don Moore, Martin Johnson

\section{Program Description}

SST maintains a satellite area located behind 710-A for hazardous waste (solvent rags) generated during training exercises for Maintenance Mechanics

Major Milestones Accomplished in FY93

- Maintained compliance with $3 Q$ manual requirements through out the year

Major Milestones for FY94

- Continue operations and maintain compliance with $3 Q$ manual requirements

Major Milestones for FY95-99

Continue operations and maintain compliance with $3 \mathrm{Q}$ manual requirements 


\title{
Site Services Division Environmental Summary
}

\author{
Department
}

Transportation (Trans.)

Mission

The Mission of the Transportation Department is to provide SRS with safe, quality, cost-effective transportation of people, products and material in a way that meets our customers needs and requirements while protecting the employee, the general public and the environment.

Vision

The Transportation Department Vision is to be the recognized model of transportation excellence through innovation, teamwork ownership of responsibility, and employee development, so that customer expectations met in a safe efficient manner.

\section{Lead Environmental Coordinator}

Karen W. Graves, 725-8900, Beeper No. 3709

\section{Environmental Coordinator}

Carrie W. Ramsey - Alternate, 725-5731

\section{Environmental Accomplishments}

The Transportation Department completed EPA/DHEC Tank Tightness \& Cathodic Protection testing requirements for fourteen (14) Underground Storage Tanks. All tanks passed and the results were reported to SCDHEC.

Two (2) Aboveground Storage Tanks have meet all EPA/DHEC Regulations.

Transportation Chemical Program includes Tier II inventory, Container Labeling Monthly Audits, and Monthly Chemical updates to Transportation Chemical Representative. 
Air Emissions Program established for fuel storage and dispensing stations.

\section{Environmental Planning}

Transportation Department's environmental programs and plans are described in the Annual Operating Plan, Capital Asset Management Plan, and Hazardous Contingency Plan, and Spill Prevention Control and Countermeasure (SPCC). Also, Transportation provide procedures which contains Department of Transportation (DOT) rules and spill \& countermeasure guidance.

\section{Environmental Challenges \& Issues from Projected Mission Changes during Next Five Years}

Some of the environmental challenges identified for Transportation Department include the following:

- New service station Underground Storage Tanks to be install for the Savannah River Forest Station.

- Abandonment of existing 619-G UST and piping tanks.

- Serving Area Facilities to meet customer fuel requirements. 


\section{Chemical Management, Pollution Prevention, and Other Compliance Programs}

Bulk Fuel Program

Program Coordinator

Karen W. Graves

Field Coordinator

Carl S. Anderson

\section{Program Description}

Transportation Department maintains and operates nine (9) fuel dispensing stations and two (2) bulk storage facilities which includes fourteen (14) underground storage tanks and three (3) above storage tanks.

\section{Organizational Responsibility}

Fuel Utilization (Essential Material) section manager the sitewide fuel and storage dispensing facilities which includes maintaining and operating nine (9) fuel stations. fourteen (14) Underground Storage Tanks (UST) and two (2) Aboveground Storage Tanks (AST).

Fuel Utilization provides monitoring and environmental testing in order to meet EPA Federal, State, and other environmental agencies regulatory requirements. In. addition, Fuel Utilization provides tested fuel for Nuclear Safety \& Critical Protection (NS\&CP) equipment.

Major Milestones Accomplished in FY93

- Implementation of a sitewide contract

- Tested Fuel program for NS\&CP Equipment

- Met EPA/DHEC Tank Tightness \& Cathodic Protection requirements 


\section{Major Milestones for FY94}

Manage the site fuel dispensing stations, bulk storage and provide fuel deliveries while maintaining environmental and safety \& health requirements and adhere to federal, state, and site rules, laws \& regulations.

Replace the existing underground fuel storage system at 620-G. Forestry Service Station in accordance with 40 CFR Regulation 61-92 part 280. Project S 4379. The completion of this project will bring the Site Service Division in compliance with the 1998 deadline for Underground Storage Tanks.

Replace diesel fuel storage tanks at 619-G in accordance with CFR 40 Regulation 61 92 part 280. Project S 4379.

\section{Major Milestont $\quad \cdot$ FY 95.99}

NONE 


\title{
Solid Waste and Environmental Restoration Division Environmental Summary
}

\section{Department}

Environmental Restoration Department (ER)

\section{Mission}

To safely remediate inactive waste and groundwater units in the most cost effective way and to ensure that the environment and the health and safety of people are well protected.

\section{Vision}

To exceed the needs and expectations of our customers and become the standard of excellence for environmental restoration through the application of experience and leading technology by highly qualified and motivated professionals.

\section{Environmental Challenges \& Issues from Projected Mission \& Changes during Next Five Years}

- Establishing a balance between remediation efforts and projected funding.

- Meeting cleanup goals with existing technology and foster technology development.

\section{Environmental Coordinators}

\author{
Mary Flora and Susan Dyer
}




\section{Chemical Management, Pollution Prevention, and Other Compliance Programs}

National Environmental Policy Act (NEPA)

Program Coordinator

Susan Dyer

Program Description

ER is responsible for maintaining compliance with appl le regulations such as the Safe Drinking Water Act, Clean Water Act. Clean Air A -oxic Substance Control Act, Endangered Species Act, and NEPA.

Major Milestones Accomplished in FY93

- Supported development of a Supplement to the Groundwater Protection EIS to incorporate ER inactive waste units.

- Developed WSRC ER Administrative Procedure ER-AP-086 entitled Completion of the NEPA Environmental Evaluation Checklist $(U)$ to facilitate NEPA compliance of ER activities.

- Initiated integration of natural resource damage concerns into the RCRA/CERCLA program.

Major Milestones for FY94

- Continue to support development of a supplement to the Groundwater Protection EIS to incorporate ER inactive waste units.

- Continue to function as Department NEPA Coordinator facilitating NEPA compliance of ER activities.

- Actively participate on the task team formed by EPD NEPA group for revision of the 3Q Manual ECM 5.1 procedure on implementation of the National Environmental Policy Act. Initiate revision of ER-AP-086 procedure. as appropriate, based on $3 Q$ Manual procedure revision. 


\title{
Natural Resource Protection, Land Use \& Wildlife
}

Land Use

\author{
Program Coordinator \\ Susan Dyer
}

Major Milestones Accomplished in FY93

Participation on Land Use Planning Steering and Technical Committees

Major Milestones for FY94

Continue participation on Land Use Planning Steering and Technical Committees

\section{Natural Resource Protection}

\section{Program Coordinator}

Susan Dyer

Major Milestones Accomplished in FY93

- Initiated annual threatened, endangered, and sensitive species surveys of ER waste unit areas which are conducted through the Savannah River Forest Service.

- Actively participated in the SRS Natural Resource Trustee Council; Natural Resource Damage Assessment (NRDA) Guidance Development Steering Committee: and SRS Natural Resource Trusteeship Ad Hoc Group to facilitate natural resource trustee activities and to integrate natural resource damage concerns into ER activities.

- Actively participated on the Natural Resource Coordinating Committee (NRCC) and the Wetlands, Aquatic Issues, and Set-Aside Area Task Groups of the NRCC.

- Developed and provided presentations on natural resource trustee activities and natural resource damage concems for ER and DOE audiences.

- Initiated development of a site-wide conceptual site model for addressing natural resource concerns on a regional or site-wide basis. Continued to participate in development of the site-wide Watershed Strategy addressing ER concerns. 
- Continued interactions and coordination of activities with the SRTC Ecology Group, SRFS, EPD, and Savannah River Ecology Laboratory on natural resource and ecological issues.

\section{Major Milestones for FY94}

- Continue annual threatened, endangered, and sensitive species surveys of ER waste unit areas which are conducted through the Savannah River Forest Service.

- Actively participate in the SRS Natural Resource Trustee Council. Natural Resource Damage Assessment (NRDA) Guidance Development Steering Committee; and SRS Natural Resource Trusteeship Ad Hoc Group to facilitate natural resource trustee activities and to integrate natural resource damage concerns into ER activities.

- Actively participated on the Natural Resource Coordinating Committee (NRCC) and the Wetlands, Aquatic Issues, and Set-Aside Area Task Groups of the NRCC.

- Revise the Ecological Risk Assessors' Guide for Evaluation of Waste Units on the Savannah River Site (ERAG).

- Continue development of a site-wide conceptual site model for addressing natural resource concerns on a regional or site-wide basis. Continued to participate in development of the site-wide Watershed Strategy addressing ER concerns.

- Provide guidance to ER professional on natural resource trustee activities and natural resource damage concerns.

- Continue interactions and coordination of activities with the SRTC Ecology Group, SRFS, EPD, and Savannah River Ecology Laboratory on natural resource and ecological issues.

\section{Major Milestones for FY95-99}

- Develop a site-wide conceptual site model for addressing natural resource concerns on a regional or site-wide basis.

- Continue to participate in activities of the NRCC and associated task groups; SRS Natural Resource Trustee Council; NRDA Guidance Development Steering Committee; and SRS Natural Resource Trusteeship Ad Hoc Group.

- Continue interactions and coordination activities with the SRTC Ecology Group, SRFA, EPD, and Savannah River Ecology Laboratory on natural resource and ecological issues. 


\section{Groundwater Protection}

Groundwater Protection

Program Coordinator

Mary Flora

\section{Program Description}

ER maintains a vast network of groundwater monitoring wells to assess impacts $\mathrm{ci}$ inactive waste units on the groundwater. Groundwater monitoring wells are also used to monitor groundwater at RCRA permitted units.

\section{Major Milestones Accomplished in FY93}

- Continue extensive groundwater characterization in General Separations Area. A/M Area, TNX Sanitary Landfill, Acid/Caustic Basins, as well as numerous waste units. Over 1,070 groundwater monitoring wells exist in these areas combined.

\section{Major Milestones for FY94}

- Release the TNX Interim Action Proposed Plan to the public to support remedial action monitoring.

- Continue extensive groundwater monitoring and characterization at RCRApermitted groundwater units and inactive waste units.

- Install the $\mathrm{A} / \mathrm{M}$ Area Vadose Zone Corrective Action Treatment units.

- Submit the F- and H-Area Seepage Basins Groundwater Operable Units Proposed Plans to the EPA and SCDHEC.

\section{Major Milestones for FY95-99}

- Begin groundwater remediation at the Sanitary Landfill, Southern Sector of MArea, the Metallurgical Laboratory, TNX, F- and H-Area Hazardous Waste Management Facilities, and Mixed Waste Management Facility. 


\section{Waste Management \& Disposal}

Waste Management

Program Coordinator

Beth Gaughan

Program Description

$E R$ is a generator of waste, primarily from investigating and closing inactive waste sites. ER practices waste minimization techniques according to the Waste Minimization Plan. Currently program initiatives are being handled by individual project managers with coordination from the Environmental Coordinators. Special projects associated with Waste Management \& Disposal activities are assigned to groups within ER on a project-by-project basis.

\section{Major Milestones Accomplished in FY93}

- Issued Environmental Restoration Waste Minimization Plan

- Initiated development of Interim Investigation Derived Waste (IDW) Management Plan

- Initiated development of the Waste Certification Program Major Milestones for FY94

\section{Major Milestones Accomplished in FY94}

- Designate Waste Management \& Disposal Program Coordinator

- Negotiate IDW Management Plan with EPA and SCDHEC Environmental Restoration

- Implement SRS investigation derived waste (IDW) management strategy

- Develop Waste Certification Program

Major Milestones Accomplished in FY95-99

- Develop Waste Certification Program

- Issue IDW Management Plan 


\section{Environmental Restoration}

\section{Environmental Restoration}

Program Coordinator

Mary Flora

\section{Program Description}

ER's mission is to clean up contaminated groundwater and inactive waste sites to ensure that the environment and the health and safety of people are protected. ER is the custodian of the SRS RCRA/CERCLA waste units, and is responsible for the investigation, assessment and closure of the units.

\section{Organizational Responsibility}

ER is responsible for remediating contaminated groundwater and inactive waste sites across the SRS.

\section{Major Milestones for FY93}

- Closure of H \& P Acid/Caustic Basins

- Integrated Demonstration Projects have matured from field demonstrations to full operation and have transferred into the ER program.

- Initiated development of a citizens advisory board to provide advice and recommendations to the DOE, EPA and SCDHEC on environmental remediation, waste management, and related activities.

- Treatment of almost 300 million gallons of contaminated groundwater in the $\mathrm{A} / \mathrm{M}$ Areas.

- Provided extensive support to DOE-SR to host the national DOE Environmental Remediation 93 conference in Augusta, GA focusing on meeting current environmental restoration challenges.

- Surface enhancements at the F- \& H-Area Seepage Basins was completed to enhance future cleanup of contaminated groundwater.

\section{Major Milestones for FY94}

- Full-scale operations of the Purged Water Disposal Station has been initiated allowing cost-effective collection of purged water from monitoring wells prior to air stripper treatment.

- Approval was received from SCDHEC and EPA to begin characterization at inactive waste units.

- Issuance of four CERCLA Records of Decision. 
- Characterization sampling is complete for F-Area Burning/Rubble Pits, M-Area West, Burma Road, Old F-Area Seepage Basin, and D-Area Burning/Rubble Pits.

- Implemented the Streamlined Approach for Environmental Restoration at the Fand H-Area Retention Basins and the D-Area Oil Seepage Basin.

- Technology demonstrations included Bentonite Mat Demo, Soil-Saw demo, vacuum extraction, bioremediation, radio frequency heating, six-phase heating, offgas E-Beam treatment, capped basin monitoring system, rotasonic drilling, electrokinetic migration, dynamic compaction, and solvent tank riser pipe video camera.

- Investigation of RCRA/CERCLA waste units.

- Continued groundwater remediation at $\mathrm{A} / \mathrm{M}$ Areas, TNX, and General Separations Area. See Groundwater section.

- Submit Closure Plans for Sanitary Landfill and Low-Level Radioactive Waste Disposal Facility to SCDHEC.

- Submit RCRA Post-Closure Care Part B Permit Applications for the Sanitary Landfill and the Mixed Waste Management Facility to SCDHEC.

- Public outreach activities included an SRS-ER program progress video, a program information brochure, educational forums, environmental forums, waste site tours, program presentations for professional, technical, and public audiences. a teacher workshop and technical paper presentations, as well as the ER program exhibit at Environmental Remediation ' 93 and Waste Management ' 94.

- Initiate closure of Sanitary Landfill

\section{Major Milestones for FY95-99}

- Closure of Sanitary Landfill, F \& K Acid/Caustic Basins, LLRWDF

- Complete investigation and assessment activities at planned RFIRI waste units.

- Begin groundwater remediation. See Groundwater section.

- Conduct CERCLA activities in accordance with the FFA, resulting in: 


\section{Solid Waste and Environmental Restoration Division Environmental Summary}

Department

Solid Waste Management Department is supported by the Solid Waste Environmental Compliance (SWEC) group. Support for some programs is currently being provided by the High Level Waste Environmental Compliance (HLWEC) group until SWEC is fully staffed.

Mission

To provide regulatory support to operating facilities in Solid Waste Management

\section{Lead Environmental Coordinator}

M. F. Tyrrell 


\section{Chemical Management, Pollution Prevention, and other Compliance Programs}

Emergency Planning and Community Right-to-Know Act (EPCRA)

Program Coordinator

K. N. Uzochuckwu (HLWEC)

Program Description

Coordinate SW and HLWM SARA III reporting. Participate in onsite SARA III subcommittee.

Major Milestones Accomplished in FY93

- Submitted SARA III Usage Report

- Submit SARA III Toxic Chemical Release Report

Major Milestones for FY94

- Submit SARA III Usage Report

- Submit SARA III Toxic Chemical Release Report

Major Milestones for FY95-FY99

- Submit SARA III Usage Report

- Submit SARA III Toxic Chemical Release Report 


\title{
Chemical Management, Pollution Prevention, and other Compliance Programs
}

\author{
National Environmental Policy Act (NEPA)
}

Program Coordinator

Ed English (SWEC) and Michael J. Hagenbarth (HLWEC)

\section{Program Description}

The National Environmental Policy Act (NEPA) Compliance Program requires that all proposed activities to be conducted/located outside of a previously developed area have an Environmental Evaluation Checklist prepared and approved before the activity may begin.

\section{Major Milestones Accomplished in FY93}

- A program was implemented within $S W$ and HLW to bring operations in compliance with $10 \mathrm{CFR}$ 1021. Engineers and Work Control personnel were trained on the procedure for completing the screening questions and Environmental Compliance Checklist which are used to determine when an Environmental Evaluation Checklist is required.

\section{Major Milestones for FY94}

- During FY93, the WMER division was split into SW\&ER and HLWM divisions. HLWEC has been supporting SWEC as Department NEPA Coordinator, but SWEC has recently gained a person who will fill those duties. Required training will be completed in late February and turnover from HLWEC to SWEC will then occur.

- Support development of the Waste Management EIS.

\section{Major Milestones for FY95-99}

- Continue to support the Waste Management EIS. As projects are rescoped based on the Site Treatment Plan currently being developed, there will be additional NEPA reviews required. 


\section{Natural Resource Protection, Surface Water \& Wetlands}

NPDES: Clean Water Act

\section{Program Coordinator}

R. S. Lewis

Program Description

Coordinate SW NPDES Program. Provide technical support for the implementation of the Stormwater Pollution Prevention Plan.

Major Milestones Accomplished in FY93

- The Stormwater Pollution Prevention Plan (PPP) was implemented as required by 10/1/93.

Major Milestones for FY94

- Establish a program to document compliance with the Clean Water Act.

- Perform quarterly PPP inspections and bimonthly NPDES outfall inspections.

Major Milestones for FY95-99

- Continue program to ensure compliance with requirements. 


\section{Groundwater Protection}

Groundwater Protection

\section{Program Coordinator}

Laura Bagwell

\section{Program Description}

Verify all groundwater monitoring complies with facilities' permits. Provide support for establishing sampling schedules for each well.

\section{Major Milestones Accomplished in FY93}

Began assessing the current groundwater program and made recommendations for improvement.

\section{Major Milestones for FY94}

- Continue program to ensure groundwater compliance.

- Continue program to ensure adequate sampling schedules for each well.

- Implement well abandonments and improvements identified.

Major Milestones for FY95-99

Continue to improve groundwater monitoring within Solid Waste Management facilities. 


\section{Atmospheric Protection}

Air Emissions

\section{Program Coordinator}

David A. Broaden

\section{Program Description}

Provide technical support and coordination to Solid Waste Management (SWM) to ensure compliance with the Clean Air Act (CAA), SARA Title III, and SCDHEC Air Pollution Control Regulations and Standards.

\section{Major Milestones Accomplished in FY93}

- Provided technical support in the development of corrective action responses to deficiencies noted in the DOE-SR F/H Area WM Facilities Radiological Air Emissions Monitoring Environmental Appraisal Report.

- Provided technical support $\mathrm{n}$ the development of corrective action responses to deficiencies noted in the EPA-IV SRS NESHAP's Inspection Report.

- Provided technical support in the coordination of the Air Emissions Inventory (AEI) effort.

- Provided technical support for SARA Title III and annual NESHAPs reporting.

\section{Major Milestones for FY94}

- Provide technical support for EPA-IV SRS NESHAP's inspection.

- Coordinate SWM AEI effort.

- Provide technical support for CAA and SCDHEC Bureau of Air Quality Control (BAQC) air permitting activities.

- Provide technical support for annual NESHAP's reporting.

\section{Major Milestones for FY95-FY99}

- SWEC will continue to attempt to staff their current vacancy in order to relieve the HLWEC Air program coordinator. 


\section{Waste Management \& Disposal}

Waste Management

Program Coordinators

Marcia Birk and Debbie Salem

\section{Program Description}

Provide technical assistance to SW facilities in proper classification and management of RCRA hazardous wastes. Provide assistance with preparation and follow-up of annual CME audit. Support SW facilities in daily compliance issues and activities.

\section{Major Milestones Accomplished in FY93}

- Assisted in revising RCRA training program.

- Developed and coordinated implementation of RCRA records program.

- Supported preparation and follow-up for the CME audit.

- Completed responses to NODs received on the RCRA Part B permit for HWSF.

- Completed draft RCRA Part B permit for TRU Waste Pads 6-17.

- Completed draft RCRA Part B permit for Solvent Tanks S33-S36.

\section{Major Milestones for FY94}

- Support annual CME audit.

- Continue support of project S-4790 to construct Solvent Tanks S33-S36.

- Continue support of SW Treatment, Storage, and Disposal facilities.

Major Milestones for FY95-99

- Support project S-4790 to construct Solvent Tanks S33-S36.

- Support annual CME audits.

- Continue support of SW Treatment, Storage, and Disposal facilities.

- Support Consolidated Incineration Facility when operational. 